\title{
When Repression Is Democratic and Constitutional: The Federalist Theory of Representation and the Sedition Act of 1798
}

\author{
James P. Martin $\dagger$
}

\begin{abstract}
This Article examines the Federalist rhetoric surrounding the brief appearance of Democratic-Republican Clubs (1794-95) and the Sedition Act of 1798. Though now universally believed anti-democratic, Federalist positions are actually a reflection of the now forgotten but in important ways superior democratic theory they held. Representation by definition requires repression since elected officials perform a political process for the people that the people are no longer permitted to perform themselves. Repression, therefore, may serve democratic ends. This simple insight permits a fresh look at Federalist rhetoric of the 1790s and the democratic processes/institutions they championed. Federalists claimed the people "deliberated" only via their representatives in the legislature and therefore that only the legislature could authoritatively declare what public opinion was or fully participate in the political deliberations of the polity. The "representative" quality of political debate justified Federalist repression. The modern system of political deliberation, in which the people "discuss" politics via the mass media and political organizations, the Federalists argued, only empowers nonrepresentative minorities. Instead, if popular participation is restricted to the right of petition and election, methods that inform and motivate representatives without intruding directly into political deliberations, the whole people can participate equally in debate via their representatives. Properly comprehending Federalist ideas radically reorients our understanding of the First Amendment and opens up many avenues of democratic reform.
\end{abstract}

\section{INTRODUCTION}

Scholarly interpretation of the role of the Sedition Act in American constitutional development is at an impasse. The Federalists, who founded this nation and led it until 1800, passed this act in 1798. There is a conflict between what the evidence indicates the Federalists believed and what modern understandings of democratic theory suggest they should have believed. The Sedition Act is an example of a seditious libel statute, and there are many indications that the Federalists accepted this kind of law. Modern commentators, however, have been unable to see how the Sedition Act, with its restrictions on freedom of speech and political association, or seditious libel laws generally, can be reconciled with the principles of representative government. The quandary, then, is, given the Act's anti-democratic-and therefore, most assume, unconstitutional-nature, how could the FedCity.

$\dagger$ Centro de Investigación y Docencia Económicas and El Colegio de México, Mexico 
eralists, who bequeathed the nation a representative form of government, knowingly have passed it?

This Article suggests that the answer to this quandary can be found when it is realized that the Federalists possessed and defended a system and theory of democracy significantly different from that which operates and is believed in today. During the 1790 s, not only in connection with the Sedition Act, but throughout the decade, especially during the controversy over the Democratic-Republican Clubs, the Federalists defended their system and articulated the coherent, plausible-but to modern eyes, quite unfamiliar-democratic theory that justified its operation. What is important about this is that, strange as it seems, the Sedition Act is perfectly democratic in the context of this theory and system. In fact, laws such as the Sedition Act played an essential and supportive role in the Federalists' democratic system. Even more surprising, Federalist ideas are arguably more democratic than modern ones, especially if one takes into account the undeveloped conditions that still prevailed in the 1790s.

The core difference between the Federalist and modern theories of representation is that the Federalists believed that the public interactions and debates that are a part of any democracy should take place via the representative mechanisms that operate through the legal institutions of the state. In other words, elected officials deliberated for the people and in their place, just as they still pass legislation on behalf of the people and in their name. ${ }^{1}$ This view is the key to understanding the Federalists' peculiar belief that the Sedition Act was justified democratically and why it is still relevant today. When a political process operates through the formal institutions of the state, the context and character of its operation can be influenced by deliberate political choice and calculated to best effect. Its quality and democratic character can therefore be improved, and, in fact, it may be that a democratic process may not occur at all if it is not organized in this way. ${ }^{2}$ A price must be paid for these advantages, however.

1 The observation that representatives deliberated for the people is not in itself new. It has been made by historians and political scientists. James Fishkin, for example, says that the Federalists envisioned a system "where the representatives would have the discussions and deliberations and come to decisions on behalf of the rest of us." James S. Fishkin, The Voice of the People: Public Opinion and Democracy 5 (Yale 1995). For similar comments, see Joseph M. Bessette, The Mild Voice of Reason: Deliberative Democracy and American National Government 1 (Chicago 1994) ("The citizenry would reason, or deliberate, through their representatives."). These and other analysts, however, have not realized the implications of this observation, that deliberating through representatives completely changes the normative and institutional structure of the system.

${ }^{2}$ It is not clear whether laws could be passed without representative structures, and 
Making a process representative fundamentally changes how it operates and entails practices and attitudes that will appear repressive and undemocratic when judged by the standards of direct democracy. Representation is a structured and indirect process. The people no longer participate directly themselves; their representatives participate for them, and public input is channeled and expressed through the mediation of these agents. Structure, however, implies repression. What commentators have failed to realize, then, is that the repressive aspects of the Sedition Act served democratic purposes by keeping public deliberation a representative, not a direct, process.

The Federalist theory of democracy has played little part in the academic controversies over the Sedition Act because it has been misunderstood and underestimated. Instead, accepting the contention that democracy depends on open public discussion, commentators have consistently misunderstood the relationship between Federalism and democracy. Interpretations for most of this century have alternated between those who, citing such instances as the Sedition Act, have condemned the Federalists as aristocratic anti-democratic reactionaries and those who, attempting to minimize the significance of these instances, have found other reasons to view the Federalists as liberal democrats. ${ }^{3}$ Even the more recent "republican" interpreters, who question aspects of liberal democracy, misinterpret the Federalists on this score. These theorists view Federalism as a fountainhead of preliberal "republican" ideas that can be eclectically appropriated to justify increased regulation and state involvement in the process

which representative structures are more democratic-proportional representation or single member districts, for example-are questions that require conscious political choice. Deliberating through the private sector, in contrast, means that great transformations, such as the shift to television politics, occur due to changes in technology and commerce, and do not reflect explicit political choice or calculation.

${ }^{3}$ Leonard Levy is the author most strongly associated with the view of the Federalists as anti-democrats. For the classic statement, see Leonard W. Levy, Legacy of Suppression: Freedom of Speech and Press in Early American History (Harvard 1964) (discussing Federalist-era attempts to suppress dissent). The latest example is Richard N. Rosenfeld, American Aurora (St. Martin's 1997) (portraying Federalists as opponents of democracy). See also David Anderson, The Origins of the Press Clause, 30 UCLA L Rev 455 (1983) (distinguishing between Federalists responsible for the Sedition Act and the original Framers). Additionally, the contradictory implications of the eighteenth century belief in both seditious libel and representative democracy have led some commentators to conclude that it is impossible to make proper sense of this period. Philip Kurland, for example, calls the intellectual origins of the First Amendment "a disorganized glop." Philip B. Kurland, The Original Understanding of the Freedom of the Press Provision of the First Amendment, 55 Miss L J 225, 257 (1985). See also Thomas I. Emerson, Colonial Intentions and Current Realities of the First Amendment, $125 \mathrm{U} \mathrm{Pa} L \mathrm{Rev} 737$ (1977) (concluding that due to a multitude of contradictions, it is "by no means clear" what the First Amendment means). 
of public discussion in ways that ameliorate some of the defects of modern democracy. ${ }^{4}$ The problem these reformers have in mind has been extensively analyzed by many democratic theorists. These theorists have long bemoaned the distortions, superficiality, and inequities present in public discussion carried on as it is now through the network of private associations, parties, and mass media that compose what is now usually called "civil society." Despite their desire to reform liberal democracy, by ignoring Federalist thought on this subject republican theorists have misunderstood the real implications of this body of thought.

Understanding the democratic system and theory lying behind the Sedition Act, however, radically changes our perspective. While the Federalists were unquestionably "liberal" in many respects, their understanding of the representative process clearly was not. While it is true they were aristocratic reactionaries, their democratic credentials were impeccable. What is more, their notion of state co-option of public discussion provides the foundation for a far more radical reform of the democratic process than any "republican" theorist has hitherto imagined and proves democratic theorists mistaken in their insistence that "civil society" is necessary for democratic functioning.

While revolutionary, howevier, Federalist ideas are far more difficult to appropriate than republican theorists have thought. ${ }^{6}$

4 In the now vast literature on republicanism, the work of Cass Sunstein and Frank Michelman is prominent. See, for example, Cass R. Sunstein, Democracy and the Problem of Free Speech (Free 1993) (drawing on the Federalist view that the First Amendment primarily serves to protect democratic self-government to reconcile various regulations with the Constitution); Cass R. Sunstein, Republicanism, Rights: A Comment on Pangle, 66 Chi-Kent L Rev 177, 177-80 (1990); Cass R. Sunstein, Beyond the Republican Revival, 97 Yale L J 1539 (1988) (arguing that certain speech-restrictive proposals are consistent with the republican ideal of deliberative democracy). For more articles on republicanism, see also Symposium: The Republican Civic Tradition, 97 Yale L J (1988); Linda R. Hirschman, ed, Symposium: Symposium on Classical Philosophy and the American Constitutional Order, 66 Chi-Kent I Rev (1990). It should be mentioned that the literature on republicanism is integrally related to the literature on "deliberative democracy" and the "public sphere," the latter inspired by Jürgen Habermas's work. See, for example, Amy Gutmann and Dennis Thompson, Democracy and Disagreement (Harvard 1996) (discussing deliberation). All three literatures are fundamentally concerned with founding democracy on discussion rather than the mechanical counting of votes, and there has been much cross-fertilization between the fields.

"Though the term "civil society" is used differently by different authors and cannot be reduced simply to political and media organizations, these groups nonetheless form major ingredients in virtually all definitions of its modern manifestation. See, for example, Jean L. Cohen and Andrew Arato, Civil Society and Political Theory ix (MIT 1992) (writing that "civil society" includes "the sphere of associations (especially voluntary associations), social movements, and forms of public communication").

6 The criticism that the appealing features of republicanism cannot be separated from its many illiberal presuppositions has been made before, but on different premises. For one of many examples, see Martin H. Redish and Gary Lippman, Freedom of Expression 
These ideas made sense in the context of undeveloped conditions lacking mass communications and a world view still imbued with hierarchical notions of a "natural order." In fact, it is their inappropriateness to the modern world that explains the early death of this system and theory. In truth, these ideas were already seriously eroding at the time the Sedition Act was passed and were thoroughly disowned in the early nineteenth century. In this context the Sedition Act was really a "last hurrah" and pyrrhic victory in a conflict between a fading "republican" and still emerging "liberal" understanding of representation and the political and social order. While the Federalists' desperate attempt to shore up their view of the constitutional order was a failure, it continues to possess relevance. Their system and theory remain part of our constitutional inheritance. Their relevance to our problems and their superiority in many aspects stand as a challenge to our more open understanding of democracy. Though the Federalist system as a whole as they understood it will never be resuscitated, it may provide elements that can be utilized to address some of our problems today. The first step in this project is to properly understand Federalist thought, and this Article will do this in a manner that is intended to clarify and frame its current relevance.

To demonstrate these points the following steps are necessary. First, a brief examination of the historical evidence informs readers of the nature of the problem addressed. Next, a theoretical section outlines the advantages of using representation and explains what the concept means and how it applies to the process of deliberation. Finally, the bulk of the Article examines the Federalist polemics of the 1790s. This last section is divided into parts dealing with the major claims of the Federalists. The first explores their central and startling assertion that public deliberation and speaking for the people can be, like passing laws, an activity reserved for elected officials. The second part examines the Federalist claim that the people are obligated to support the poli-

and the Civic Republican Revival in Constitutional Theory: The Ominous Implications, 79 Cal L Rev 267, 268 (1991) ("Once the morally deplorable elements from its past are excised, the classical concept of civic republicanism may no longer be conceptually viable."); Steven G. Gey, The Unfortunate Revival of Civic Republicanism, $141 \mathrm{U} \mathrm{Pa} \mathrm{L} \mathrm{Rev} \mathrm{801,} 803$ (1993) (demonstrating that classical civic republicanism conflicts with both ends of the current political spectrum); Morton J. Horwitz, Republicanism and Liberalism in American Constitutional Thought, 29 Wm \& Mary L Rev 57, 67 (1987) (suggesting that republicans "will not easily fit [today's] liberal or republican models"); Thomas L. Pangle, The Classical Challenge to the American Constitution, 66 Chi-Kent L Rev 145 (1990). These criticisms have also been made in the social sciences. See, for example, Don Herzog, Some Questions for Republicans, 14 Political Theory 473, 473-95 (1986). 
cies and pronouncements of their officials, as they are obligated to obey laws. Third, the sound reasons why the Federalists thought their system more democratic than the modern alternative are shown. These three parts together form the core of the Federalist challenge to current First Amendment thinking. A fourth part explores the legal and political processes that constituted the Federalist system of representation and enabled their representatives to deliberate democratically for the people. The general parameters of Federalist First Amendment thought that are implied by those processes are examined in the fifth part. The last part examines the enormous ambiguities and barriers that inhibit the current utilization of Federalist theory but concludes with the hope that useful elements can be salvaged.

\section{HISTORICAL SETTING}

Since the Sedition Act was part of a larger battle over the principles of representative government that occurred in the 1790 s, it cannot be considered in isolation. The controversy with the Democratic-Republican Clubs is especially significant since the Sedition Act is really the culmination of the former episode, the principles involved being identical. Trying to make sense out of both the Sedition Act and the debate of the clubs presents a historical riddle that is easily summarized.

The Sedition Act had two parts. The first part, whose significance has been virtually ignored by commentators, proscribed organized opposition to public measures. ${ }^{7}$ The second made it illegal to criticize government, provided the criticism was malicious, untrue, alienated the people's affections from their government, or brought the government into the contempt of the people. The sec-

7 See An act for the punishment of certain crimes against the United States, 5 th Cong, 1st Sess, in III Annals of Cong 3776-77 (July 14, 1798) (Gales and Seaton 1851). All but a few specialists on this subject have overlooked the fact that freedom of association issues were also involved. See Charles E. Rice, Freedom of Association 124 (NYU 1962) (making this point).

Freedom of association as an issue was also largely ignored at the time. Congressman Robert Goodloe Harper commented on this matter in a letter circulated to his constituents, dated February 10, 1799. He stated that the "first section," banning organized opposition to government, "has never been complained of, nor has any objection been made to its constitutionality. The objections are confined to the second section." Robert Goodloe Harper, Letter to His Constituents (Feb 10, 1799), in Noble E. Cunningham, Jr., ed, 1 Circular Letters of Congressmen to Their Constituents, 1789-1829 146, 147 (UNC 1978). See also Rice, Freedom of Association at 124 . The Congressional Record also reveals no complaints specifically against the first section despite the many complaints about the other section. See Report of Committee On Alien and Sedition Laws, III Annals of Cong 2987 (Feb 25, 1799). This was pointed out by Thomas F. Carroll, Freedom of Speech and of the Press in the Federalist Period: The Sedition Act, 18 Mich L Rev 615, 617 (1920). 
ond provision appears to be a clear violation of freedom of speech and the first of freedom of political association.

From the perspective of commentators today, few things seem as obvious as the fact that the Sedition Act violated certain fundamental principles of representative democracy embodied in the United States Constitution. This is the virtually unanimous opinion of all political scientists, historians, and legal scholars who have examined the Act, and this view has been expressly embodied in a number of court cases. ${ }^{8}$ This view, in fact, has been almost universal since the middle of the nineteenth century when the Act was explicitly disowned by Congress and was condemned even by such fairly conservative figures as Henry Adams and John C. Calhoun. ${ }^{9}$

${ }^{8}$ The literature discussing the essential role that freedom of speech and association play in democratic systems is, of course, copious. As one modern commentator has said, "Governments are called 'democracies' when they permit freedom of speech and press. States that put down critics are taken to be undemocratic." Frederick Schauer, Free Speech and the Argument from Democracy, in J. Roland Pennock and John W. Chapman, eds, Liberal Democracy: Nomos XXV 241 (NYU 1983). Another argued that "[ $t]$ he concept of seditious libel strikes at the heart of democracy .... [D]efamation of the government is an impossible notion for a democracy." Harry Kalven, Jr., The New York Times Case: A Note on "The Central Meaning of the First Amendment", $1964 \mathrm{~S} \mathrm{Ct}$ Rev 191, 205. See also Zechariah Chafee, Jr., Free Speech in the United States 19-20 (Harvard 1941) (citing freedom of expression as a key difference between the Constitution and British rule); Michael T. Gibson, The Supreme Court and Freedom of Expression from 1791 to 1917, 55 Fordham L Rev 263, 272 (1986) ("Modern writers find the concept of seditious libel to be flatly incompatible with the existence of a republican form of government in which the people are sovereign."); Alexander Meiklejohn, Free Speech And Its Relation to Self-Government 90 (Harper \& Brothers 1948) (calling freedom of speech the "principle upon whose integrity the entire structure of government by consent of the governed rests"). Similarly, in terms of freedom of association, one analyst said, "Government by the people is based on every person's right . . . to organize in groups, to question the decisions of the government, and to campaign openly against it." James MacGregor Burns, et al, Government by the People 89 (Prentice Hall 15th ed 1993). These libertarian principles are now generally viewed as being inherent in the Constitution, especially in the First Amendment with its freedom of speech, press, and assembly clauses. For this reason, the Sedition Act is considered by many to have been patently unconstitutional. The Supreme Court voiced this opinion in dicta when it declared in New York Times $v$ Sullivan, 376 US 254 (1963), that the Act violated the "central meaning of the First Amendment." Id at 273. As Justice Black wrote in a separate concurring opinion, the Sedition Act "by common consent has generally been treated as having been a wholly unjustifiable and much to be regretted violation of the First Amendment." Id at 296 (Black concurring).

9 In 1840-44, Congress, for example, took the unusual step of repaying the fines that had been assessed during the Act's enforcement. See Alan J. Farber, Reflections on the Sedition Act of 1798, 62 ABA J 324, 328 (1976), citing 6 Stat 802. For summaries of nineteenth and early twentieth century free speech doctrine, see George Chase, Criticism of Public Officers and Candidates for Office, $23 \mathrm{Am} \mathrm{L}$ Rev 346 (1889) (comparing various late nineteenth century libel laws); Gibson, 55 Fordham L Rev at 272-92 (cited in note 8); Norman L. Rosenberg, The Law of Political Libel and Freedom of Press in Nineteenth Century America: An Interpretation, 17 Am J Legal Hist 336 (1973). 
What can be said of the Sedition Act can also be said of Federalist hostility to the Democratic-Republican Clubs. These clubs appeared throughout the nation after the Frenchman Edmond Genet visited in 1793. The clubs enjoyed only a brief existence, since public hostility to them was great. On the floor of the House, for example, only a few congressmen would openly defend them. ${ }^{10}$ That there was any controversy over these clubs at all reveals how inconsistent Federalist beliefs are with the canons of modern democracy. The clubs, after all, were engaged in activities that are unobjectionable when judged by the standards of modern democracy, and are actually considered to be necessary to its proper functioning. These clubs were organizations of likeminded individuals attempting through persuasion to mobilize public opinion behind various causes and philosophies, including opposition to government policy. The techniques they used to accomplish their ends shared much in common with modern political parties. ${ }^{12}$ Modern scholars view their emergence as a watershed event and discern in their organization and behavior the embryonic features of modern day political parties. ${ }^{13}$

\footnotetext{
${ }^{10}$ The minority who defended the clubs, of course, was composed of Jeffersonians, not Federalists. Many of them, it should be noted, were markedly ambivalent about the impact these clubs had on a republican political system. For more on the clubs, see Stanley Elkins and Eric McKitrick, The Age of Federalism ch 10, 11 at 451-61 (Oxford 1993); Eugene Perry Link, Democratic-Republican Societies, $1790-1800$ (Columbia 1942).

${ }^{11}$ A standard interpretation of twentieth century political science has been that organizations, especially parties, play an essential role in forming and articulating public opinion and in enunciating alternatives so that the public can choose. See, for example, Frank Bealey, Democracy in the Contemporary State 37 (Clarendon 1988) ("[R]epresentative democracy . . . almost inevitably implies the formation of political parties. Parties are needed to inform electorates, articulate programmes, and aggregate voters."); Stephen K. Bailey, Howard D. Samuel, and Sidney Baldwin, Government in America 541 (Holt 1957) (stating that parties "are among the most significant instruments of democracy[ ] ... [since they] are the great mobilizers of majorities"); Robert G. Dixon, Jr., Representation Values and Reapportionment Practice: The Eschatology of "One-Man, One-Vote", in J. Roland Pennock and John W. Chapman, eds, Representation: Nomos X 167, 173 (Atherton 1968) (mentioning the "crucial role of parties as opinion-organizers").

${ }^{12}$ Clubs prepared slates of candidates, held party meetings, and communicated with other clubs throughout the nation. A contemporary noted "that they agree on town committees, drafts of resolutions, and the candidates for elections, that they cabal to carry points, and that they so carry them." Deodatus-No. II, Columbian Centinel 1 (Sept 27, 1794).

${ }^{13}$ See Bernard Fay, Early Party Machinery in the United States: Pennsylvania in the Election of 1796, $60 \mathrm{~Pa}$ Mag Hist and Biog 375, 387-88 (1936); William Miller, First Fruits of Republican Organization: Political Aspects of the Congressional Election of 1794, 63 Pa Mag Hist and Biog 118, 141-43 (1939). Traditionally, extra-legal political organizations had viewed themselves as temporary. They typically grew out of crises but were expected to disband when the particular problem passed. What was innovative about the clubs is that they believed that extra-legal political organizations must exist as ongoing, permanent elements in the representative system. They also believed that the whole citizenry should be involved with them. For example, the clubs invited all "[t]o associate yourselves in political societies." Democratic Society of Pennsylvania, Address to the Citizens of the United States, Baltimore
} 
Ironically, despite the fact that the principles embodied in this Act, or exemplified in the Federalists' anti-club attitudes, are universally considered incompatible with the Constitution and representative democracy today, this was not the case at the time. As much scholarship has pointed out, seditious libel laws and hostility to and restrictions on political association had coexisted with representative government in America since the first settlement. ${ }^{14}$ In the late eighteenth century, political parties still had few open defenders and even the Sedition Act's opponents were motivated more by their fear of national power than the belief that such an act was inconsistent with democratic govern-

Daily Intelligenser 1 (June 14, 1794).

it For a discussion of colonial seditious libel laws, see Harold L. Nelson, Seditious Libel in Colonial America, 3 Am J Legal Hist 160 (1959). For the English background, see Philip Hamburger, The Development of the Law of Seditious Libel and the Control of the Press, 37 Stan L Rev 661 (1985). See also W.R. Vance, Freedom of Speech and of the Press, 2 Minn L Rev 239, 242-48 (1918) (discussing English and colonial practices). As Edward S. Corwin, among others, stated seventy years ago, the Federalist Framers accepted this tradition and did not think they were rescinding the common law of seditious libel when they passed the First Amendment. Edward S. Corwin, Freedom of Speech and Press under the First Amendment: A Resume, in Douglas B. Maggs, et al, eds, 2 Selected Essays on Constitutional Law: Limitations on Governmental Power 1060 (Foundation 1938); Carroll, 18 Mich L Rev at 633-34 (cited in note 7). It is important to note that the interpretation associated with Leonard Levy-that the First Amendment was not originally understood as invalidating seditious libel-had a long history before the publication of his controversial Legacy of Suppression in 1964 (cited in note 3). The interpretation had simply been less popular for the previous forty or so years. Even Zechariah Chafee, Jr., although primarily responsible for creating the dominant twentieth century interpretation that the First Amendment proscribed prosecutions for seditious libel, appears later to have come to conclusions not that different from Levy's. Strangely, no one seems aware of this, and Chafee is identified only with his earlier opinions. See, for example, Zechariah Chafee, Jr., Book Review, 62 Harv L Rev 891, 898 (1949), reviewing Alexander Meiklejohn, Free Speech: And its Relation to Self-Government (Harper 1948); Zechariah Chafee, Jr., The Great Liberty: Freedom of Speech and Press, in Alfred H. Kelly, ed, Foundations of Freedom in the American Constitution 52, 86-87 (Harper 1954).

John Marshall was typical not only of his political affiliation but also of his era when he said, referring to seditious libel, that "this liability to punishment for slanderous and malicious publications, has never been considered as detracting from the liberty of the press." John Marshall, Upholding the Alien and Sedition Acts (1798), in John P. Roche, ed, John Marshall: Major Opinions and Other Writings 32, 46-47 (Bobbs-Merrill 1967). See also Walter Berns, Freedom of the Press and the Alien and Sedition Laws: A Reappraisal, 1970 Sup Ct Rev 109, 132 (noting that the Framers believed that the First Amendment prohibited only prior restraints); Carroll, $18 \mathrm{Mich}$ L Rev at 649 (suggesting that Republican opposition to the Sedition Act was based on states' rights rather than freedom of expression); Corwin, Freedom of Speech and Press at 1063. See generally Leonard W. Levy, Emergence of a Free Press (Oxford 1985) (revising the author's previous indictment of the Framers as not believing in true freedom of expression in Legacy of Suppression, but maintaining that the Framers believed in a narrower scope of freedom than the modern view); Kurland, 55 Miss L J at 232-36, 243-48, 253 (cited in note 3) (arguing that eighteenth century Englishmen and Americans generally saw no conflict between freedom of the press and proscriptions on seditious libel); James Morton Smith, Freedom's Fetters: The Alien and Sedition Laws and American Civil Liberties 127-28 (Cornell 1956) (same). 
ment. ${ }^{15}$ Perhaps most amazing about this tradition, of which the Federalists were the last standard-bearers, is how tenaciously its defenders argued that protecting the reputation of rulers and repressing political associations were necessary to representative government. Although the literature of that era is full of such defenses, scholars have not taken them seriously, viewing such claims as too bizarre, incoherent, and "paradoxical" to be anything more than unprincipled polemics. The Federalists, for example, in the most obvious contradiction to modern democratic tenets, argued that opposing and campaigning against govern-

${ }^{15}$ Reactions to the first and second clauses of the Act can be considered separately. Regarding the second, even a majority of the Act's Jeffersonian detractors implicitly conceded the compatibility between the principles of the Act and those of representative government. Only a few of the bill's opponents, after all, justified their stand on the ground that such an act was incompatible with representative democracy. Indeed, many of those who opposed the federal statute took no exception to, or even supported, similar actions at the state level. For example, as a reason for not passing the bill, Representative Macon noted, with no apparent disapproval, that "persons might be prosecuted for a libel under the State Governments," and that therefore no national statute was necessary. II Annals of Cong 2106 (July 5,1798 ).

Similarly, some of the Act's staunchest enemies, such as Thomas Jefferson, later approved or instigated seditious libel prosecutions in their states. See, for example, Farber, $62 \mathrm{ABA} J$ at 327-28 (cited in note 9) (commenting on Jefferson's support of seditious libel prosecutions during his administration); Thomas Jefferson, Letter to Mrs. Adams (Sept 11, 1804), in Albert Ellery Bergh, ed, 11 The Writings of Thomas Jefferson 49, 51 (Jefferson Memorial Assn 1905) (arguing that state governments have exclusive jurisdiction to regulate the press); Leonard W. Levy, Jefferson and Civil Liberties: The Darker Side 46-48 (Harvard 1963) (same). Jefferson, it appears, not only was unopposed to state prosecutions for seditious libel, but was not even consistently opposed to them on a national level. See, for example, Robert George Wetmore, Seditious Libel Prosecutions in 1806 in the Federal Court in Connecticut; United States v. Tapping Reeve, and Companion Cases, 57 Conn Bar J 196 (1983) (chronicling a seditious libel prosecution during the Jefferson Administration).

The fact that most of the states had both free speech provisions in their constitutions and seditious libel statutes on their books serves as further confirmation that most statesmen in the generation of the Founders saw no contradiction in principle between seditious libel laws and the free speech requirements of a representative government. See, for example, Berns, $1970 \mathrm{~S} \mathrm{Ct} \mathrm{Rev} \mathrm{at} 121$ (cited in note 14) (noting support for state sedition laws); Farber, 62 ABA J at 327-28 (supporting sedition laws); Leonard W. Levy, Liberty and the First Amendment: 1790-1800, 68 Am Hist Rev 22, 30 (1962) (noting support for state sedition laws). But see Hortensius, An Essay on the Liberty of the Press (1799), in George Hay, Two Essays on the Liberty of the Press (Da Capo 1970) (supporting state sedition laws but opposing the Sedition Act).

It should be mentioned, as Levy points out, that arguments that seditious libel laws were inconsistent with representative government began to appear after the passage of the Sedition Act. Judging from the newspapers, however, these arguments still possessed a secondary, not primary, character. See Levy, Emergence of a Free Press at 282-349 (cited in note 14).

The first section of the Act was much less controversial. The opinion that parties were detrimental to representative government remained standard well into the nineteenth century. See Ronald P. Formisano, The Transformation of Political Culture: Massachusetts Parties, 1790s-1840s 88-89 (Oxford 1983) ("If anyone publicly defended 'party' or 'party spirit' as inherent goods before 1815 , it was a rare event."). See also discussion in note 7. 
ment measures was undemocratic since the majority had elected the government to make policy decisions; they therefore argued that by obstructing the government, one obstructs the majority. Similarly, abusing those in office, instead of being an expression of the democratic right of free speech, was anti-democratic, because to insult elected officials was to insult the people who elected them.

\section{THE CONCEPT OF REPRESENTATION}

To understand the Federalist positions on political speech and association, one must place them within the context of their broader theory of representation. This Section begins there, examining the core concepts of representation, then moves on to define "deliberation" and asks what it means to deliberate through representatives. It constructs an outline of an unfamiliar Federalist system, one that will allow us to make sense of Federalist rhetoric in the context of an overall system of democratic representation.

Representation can take place in an extraordinarily wide range of manners and senses, yet theorists generally agree on its core meaning. Representation denotes making a thing "present again" or "re-present" in something else in which it is not actually present. ${ }^{16}$ Or, as another scholar has put it, "representation" is the "presence of that which is absent."17 And here is the paradoxical duality at the core of representation: two things that are different and distinct must, at the same time, in some sense, be the same thing.

From this duality emerge the two necessary conceptual characteristics of representation. First, in order for one thing to be "present again" in something else, the something else must have a recognizably separate identity and existence from the original it represents. Secondly, and paradoxically, it must share in the same identity as the original; otherwise, the original would not be making it "re-present." If either "separation" or "identity" is not maintained, the conceptual integrity of the representation, and

\footnotetext{
${ }^{16}$ See Hanna F. Pitkin, The Concept of Representation 144 (California 1967).

${ }^{17}$ Anne Norton, Reflections on Political Identity 15 (Johns Hopkins 1988). For statements similar to Norton's and Pitkin's, see Harold F. Gosnell, Democracy: The Threshold of Freedom 131 (Ronald 1948), citing John A. Farlie, The Nature of Political Representation, 34 Am Pol Sci Rev 236, 236 (1940) ("Etymologically, the literal meaning of represent is to "present again,' and from this it has come to mean to appear in place of another."); Representation, in 23 Encyclopedia Britannica 108, 109 (11th ed 1911). See also Harvey C. Mansfield, Jr. and Robert G. Scigliano, Representation: The Perennial Issues (Am Pol Sci Assn 1978) (discussing the philosophical and political theories underpinning various mechanics of representation).
} 
hence its practical utility, is placed in jeopardy. A painting of an apple demonstrates this point. The painting can only represent the apple because, on the one hand, the painting, constructed of oil and canvas, is something very different from the fructose and fiber that the apple is made of; yet on the other hand, due to color and form, the painting resembles the apple. If the painting or the subject were made of the same materials, or shared no resemblance, however, it would not be clear if representation was taking place, and the painting could not serve practically as a picture of an apple.

Because the paradoxical identity and separateness between two objects establishes the underlying dynamics essential to representation, it is there that one must look for the advantages political representation offers as well as the structure it imposes. The advantage of representation is that it permits a process to be performed by different people in different contexts and to be counted as the same. Because the people as a whole cannot meet and pass laws, modern democracy uses the fiction of representation to permit representatives in the legislature to pass laws that are considered to be passed by the people themselves.

Enjoying the advantages of representation, however, depends on maintaining its structure, and for this reason it is essential to ask just what the twin concepts of identity and separateness mean in terms of political institutions and norms. ${ }^{18}$ The specific constitutional provisions allowing legislators to pass laws create "separateness" by denying the people the right to do the same directly. This is repression because the people are explicitly barred from what is the most democratic of activities. Whatever benefits representation offers, however, are only available if this "repression" is maintained. ${ }^{19}$ Likewise, in the modern context, other institutions and norms, such as elections and laws protecting freedom of speech and association, create "identity" between the peo-

\footnotetext{
${ }^{18}$ I am here speaking of representation as agency, since although representation exists in many senses in representative government, its manifestation as agency is the dominant one. Due to the depth and range of the concept, there are no political systems that are not "representative" in some sense. Even a hereditary tribal chief, after all, "represents" his people in at least the symbolic sense, since the power and majesty of his office embody their power and majesty. The presence of elections means that the leaders are the appointed agents of the people. For a general discussion of the different types of representation, see Pitkin, The Concept of Representation (cited in note 16); A. Phillips Griffiths, How Can One Person Represent Another?, in The Aristotelian Society, Supplementary Volume XXXIV 187 (Harrison 1960).

${ }^{19}$ Those instinctively suspicious of the possibility of conducting democratic deliberations through representative mechanisms should ponder how an ancient Athenian might respond to modern representative government. Would he call a nation in which only a few hundred citizens out of many millions are permitted to vote on legislation a democracy?
} 
ple and the actions of their representatives by encouraging an active political life. This identity gives the laws their legitimacy; ${ }^{20}$ if it is lost, so is the validity of the system.

The point of discussing the core principles of representation, of course, is to demonstrate that democracy and repression are the same thing in representative government, and to clarify the underlying dynamics so that they can be applied to the unfamiliar area of "deliberation." As it is used here, deliberation refers both to the interactive process through which the whole people form their judgments in a democracy and to the forum in which this process takes place. More specifically, it will be used to refer only to this "discussion of the whole" and in no way exhausts all the types of political communication and deliberation that occur in a democracy. ${ }^{21}$

To understand how representatives can deliberate for "the people," it is necessary to understand two elements of deliberation. First, it is the process through which different parties interact and decide together. Second, through this process, inchoate elements, such as feelings and facts, are formed into considered judgments and decisions. To say that the representatives deliberate for the people is to say that they do and must perform both of these functions. That is, they must receive the unformed elements-undeveloped local sentiments and information about conditions-in order to validly form them into the considered judgment of the whole community.

\footnotetext{
${ }^{20}$ For at least the last century and a half, the dominant normative justification of democratic government has been that it implements the actions the people want, the "will" of the people being "re-present" in the policies of the government. While this idea retains powerful normative vibrancy, whether or not this really happens empirically has been a much debated question. As a recent scholar explained, "The idea of representation is based on ... the concordance between ... the will of the represented and the policy of the representatives. In the classical concept [of representation] there should be a rather metaphysical identity between the will of the nation . . . and the action of representatives." Marek Sobolewski, Electors and Representatives: A Contribution to the Theory of Representation, in Pennock and Chapman, eds, Representation: Nomos X 95, 105 (cited in note 11). See also Wilder W. Crane, Jr., Do Representatives Represent?, 22 J Politics 295 (1960).

${ }^{21}$ The processes outlined here under the term "deliberative process" are basic to virtually all definitions of democracy. In fact, in the past ten to fifteen years, at least in the minds of many theorists, deliberation has been transformed from merely an essential element of democracy to its basis. Before the current enthusiasm for "deliberative democracy" (there is now virtually nothing written in democratic theory that is not about deliberation), the same ideas were expressed, but under different names. For example, many authors used "discussion" as their organizing concept. See, for example, R. Bassett, The Essentials of Democracy, in Constructive Democracy 77, 80 (George Allen \& Unwin 1938); Arthur Bryant, The Foundations of Democracy, in Constructive Democracy 51, 66 ("Democracy" is "a form of government by discussion."); George E. Marcus and Russell L. Hanson, eds, Reconsidering the Democratic Public (Pa State 1993) (collecting essays that study empirically what goes on in modern democracies when the public deliberates).
} 
Given this definition of deliberation, several aspects of the governmental structure needed to support it become clear. First, the system must enable the representatives to deliberate for the people and keep the people from doing it themselves. It must, however, also possess structures that maintain "identity" between the legislators and the people. These requirements suggest a vertical system in which political communication flows up from the individual localities to elected officials, providing them with the information they need to deliberate for the people. ${ }^{22}$ Second, the system must maintain this vertical pattern (separation) through legal and normative prohibitions on direct "deliberation" amongst the people. Third, because judgment is formed in deliberation, representatives should possess the right to state the authoritative opinion of the people, and this right should be supported through patterns of political deference to the elected officials.

Representation provides the advantages of better qualified deliberators, located in an environment more conducive to quality discussion. Because the people deliberate through the representative mechanisms of the state, their access to this process can be more evenly, hence democratically, distributed than through direct participation in "civil society." The Federalist system can plausibly claim to fall directly into this broad description of a representative democracy, and Federalists did in fact claim all of the accompanying advantages, especially the one regarding more democratic access to the process of deliberation. The not insubstantial merit of those claims emerges clearly in the following more detailed examination of the Federalists' own rhetoric.

\section{THE FEDERALIST POLEMICS OF THE 1790S}

A. Discussing Politics Through the Representative

Organs of the State

Since the core normative claim of the Federalists-that the government should deliberate for the people-is startling given modern sensibilities, its parameters need to be established first

\footnotetext{
22 Other scholars have noted that the eighteenth century system possessed vertical characteristics, and that the people of different constituencies related to each other not directly, but through their representatives. Here representative devices served a useful function by compartmentalizing the subjects into divisions beneath their representatives. "The representative relationship facilitated communication vertically between subject and representative but not horizontally between subjects of different constituencies. ... [T]he only normal communication they had with their fellow subjects in the political arena was through the medium of their delegates." Richard Buel, Jr., Democracy and the American Revolution: A Frame of Reference, 21 Wm \& Mary Q 165, 189 (1964).
} 
and in some detail. As we shall see, the Federalists raise disturbing normative questions for defenders of modern democracy regarding the location of public discussion and the moral claims participants may make. Because at their root their battles with the radicals stemmed from a conflict between two theories of representation, the Federalist contentions were implicit or explicit at the precise points these theories conflicted.

To grasp this point, however, a brief outline of the modern system the Federalists rejected is useful. Although still only an embryo, the radicals had begun to enunciate its basic principles. ${ }^{23}$ In the modern system the people themselves discuss and decide basic political issues, and they do this largely through the plethora of competing political organizations that exist in "civil society."24 Through these organizations, they examine and judge political questions and presume both to tell and force the government to do their bidding. The government, in theory at least, simply implements the "public opinion" that develops among the people as they deliberate. ${ }^{25}$ What is more, these organizations claim to speak for large sections or majorities of the people. They have both the right as well as the motivation to do so. As public opinion aggregators who make their claim to political power based on the strength of their popular following, they would destroy their position by stating they had no support. ${ }^{26}$

${ }^{23}$ For a good collection of their thoughts and pronouncements, see Philip S. Foner, ed, The Democratic-Republican Societies, 1790-1800: A Documentary Sourcebook of Constitutions, Declarations, Addresses, Resolutions and Toasts (Greenwood 1976) ("A Documentary Sourcebook").

20 The role of private political organizations in the formation and articulation of public opinion and in the forcing of the government to respond is a conventional assertion in the political science literature. Earlier in this century this took the form of near worship of political parties and more recently it has been integrated as an aspect of the "civil society" literature. See, for example, Bailey, Samuel, and Baldwin, Government in America at 541 (cited in note 11); Bealey, Democracy in the Contemporary State at 37 (cited in note 11); Dixon, Representation Values and Reapportionment Practice at 178-80 (cited in note 11).

${ }^{25}$ This notion can be expressed in different ways. Older writings often said that governments obeyed the "will of the people." Writers now talk in terms of public control-the ability of the people to make the government do what they want it to do-or in terms of the congruence of public opinion and government policy. See, for example, Bealey, Democracy in the Contemporary State at 6 (cited in note 11); Robert A. Dahl, A Preface to Democratic Theory 3 (Chicago 1956) (writing on "control" formulations); Barry Holden, The Nature of Democracy 8 (Barnes \& Noble 1974); H.B. Mayo, An Introduction to Democratic Theory 60 (Oxford 1960); Dorothy Pickles, Democracy 137 (Basic Books 1970) ("[T]he essence of democratic government is the accountability ... to the electorate."). For "public opinion" formulations, see note 20.

${ }^{26}$ It follows from this that they speak for and to polity-wide audiences. They therefore must express their demands in terms of the people's preferences and desires, and similarly must exaggerate the base of their popular support. 
The Federalists rejected this democratic system. Because it was the legislature that was supposed to discuss, decide, and speak for people, when organizations did this they saw only the individuals involved, not the "people."27 The Federalists saw the activities of these clubs as well as the modern rhetorical stances they adopted as outrageous usurpations of the prerogatives of elected officials. Additionally, since they believed themselves defending the only conceptually defensible theory of representation, the Federalists charged the radicals with what appeared, quite accurately from their position, to be a variety of intellectual absurdities. It needs to be emphasized that in these altercations the Federalists clearly identified and unambiguously rejected the central institutional and conceptual features of the modern system.

Perhaps from the modern perspective the most startling and most obvious example of Federalist theory is its charge that the club activities and rhetorical claims were illegitimate because the clubs had no electoral foundation. What makes this criticism so revealing is that given modern assumptions it is bizarre, making absolutely no sense. Since from the modern perspective the clubs are carrying on perfectly ordinary democratic activities, and are rhetorically claiming no more than popular support, the Federalists' claims seem strange indeed.

One of the most common complaints against the clubs was that they claimed to speak for the people, but had not been elected to do so. Though Federalist theory permitted individuals or small delimited groups to speak for themselves, the Federalists viewed attempts to speak for the nation as infringing on the role of elected officials. ${ }^{28}$ As one Federalist pointed out, representative bodies, not the clubs, were the "well-constituted organs of the People's will."29 Accordingly, only elected officials, "the constituted organs of the people," could properly express "the general will of the nation." ${ }^{30}$ For this reason, the modern rhetorical stance of the radicals grated against Federalist ears. The Federalists complained that the Democrats went so far "as to stile themselves the

\footnotetext{
${ }^{27}$ Today, for example, the right of ten people to hand out leaflets is defended on the grounds that the "people" have a right to agitate politically. Believing this right delegated, the Federalists would not view these ten people under the rubric of "the people," and would consequently see only ten malcontents.

${ }^{28}$ For the roles of individuals or small groups, see Section III.D, especially III.D.1 and III.D.2.

${ }^{29}$ Representative Murray, IV Annals of Cong 907 (Nov 25, 1794).

${ }^{30}$ Samuel Kendal, A Sermon Delivered on the Day of National Thanksgiving 29 (Samuel Hall 1795) ("Thanksgiving Sermon").
} 
people" and claim that they "were the people."31 As Congressman Ames explained: "They have arrogantly pretended sometimes to be the people, and sometimes the guardians, the champions of the people. They affect to feel more zeal for a popular Government, and to enforce more respect for Republican principles, than the real Representatives are admitted to entertain." ${ }^{\prime 32}$

Another Federalist complained of these "societies stiling themselves democratic without emanating from the choice of the people, or deriving any authority from that only pure fountain of power."33 Yet another Federalist summed up the argument: "Those chosen by the people to administer their government are the proper organs to express the general will of the nation; and no other body ... has a right to assume this authority, or to pretend to be the people." 34

If the people speak through their elected officials, then it becomes self-contradictory to claim to speak for the people yet publicly disagree with the government. One Federalist complained that while the clubbists "have impudently stiled themselves friends of the people, nay, the people themselves, . . . they have constantly opposed . . . every act of the people as declared by their representatives, in their legislature." Another asked, "Is this most remarkable for impudence or inconsistency?"36

Claiming to speak for the people in the modern sense, of course, is inextricably connected to the rhetorical stance of claiming to decide public questions, telling the government what to do, and reaching out for further public popular support. The Federalists objected to these radical postures as well. They complained that the clubs (with no electoral basis) "spoke with the voice of decision"37 and "assume[d] the right . . . exclusively and definitively to pass sentence upon" government actions. ${ }^{38}$ Equally offensive was their predilection to "dictate to the regularly constituted authorities of the nation"39 and to garner public support by "arraign[ing] before the public the men and measures of the" government. ${ }^{40}$

${ }^{31}$ For the Columbian Centinel, Columbian Centinel 1 (Sept 27, 1794).

${ }^{32}$ Representative Ames, IV Annals of Cong 923 (Nov 26, 1794).

${ }^{33}$ Marcellus-No. I, Gazette of the United States 1 (Nov 20, 1794).

${ }^{34}$ Kendal, Thanksgiving Sermon at 28-30 (cited in note 30).

${ }^{35}$ Manlius-No. I, Columbian Centinel 1 (Sept 3, 1794).

${ }^{36}$ Deodatus-No. II, Columbian Centinel 1 (Sept 27, 1794).

${ }^{3}$ Hezekiah Packard, Federal Republicanism Displayed in Two Discourses 28 (John Russell 1799).

${ }^{38}$ For the Columbian Centinel, Columbian Centinel 1 (Sept 27, 1794).

${ }^{39}$ Anti-Club, Columbian Centinel 1 (Aug 27, 1794).

to For the Columbian Centinel, Columbian Centinel 1 (Sept 27, 1794). See also Pack- 
The radicals' rhetorical stance, of course, followed from their desire to shape public opinion and political decisionmaking. The Federalists objected to this, too. In Congress, for example, clubs were condemned because, though not elected, they "had arrogated the management of public opinions and affairs." ${ }^{\prime 1}$ George Washington felt the same way, and in a communication to Congress he condemned the clubs and their "proceedings, which would arrogate the direction of our affairs, without any degree of authority derived from the people." ${ }^{\text {"42 }}$ Federalists complained that "combinations and societies ... not established by public authority" were influencing the course of the nation. ${ }^{43}$ One Federalist, afraid of the clubs' influence, reassured himself that the clubs would ultimately fail because the people preferred their nation's course to be steered by "rulers [who] are chosen," rather than by "jacobin clubs . . . who wish by their resolves, to guide the affairs of the empire." Another journalist, after explaining that in a "representative government" the people "govern" only through their representatives, complained: "Yet our clubbists pretend to be advocates for the power of the people, when they openly affect to check, guide and influence public measures in some other way, a way in which neither the people nor their representatives can have any agency." ${ }^{.45}$

The Federalists understood, of course, that in order to deliberate and create public opinion, it was necessary to criticize and examine current events. But since they believed that the process of deliberation should take place only in the legislature, they made a great distinction between the latitude of speech given a representative, who was expressly elected to discuss public affairs, and that given an ordinary person. ${ }^{46}$ So, for example, when

ard, Federal Republicanism at 27 (cited in note 37) (warning against the influence of parties). Examples of the Federalists condemning the radicals' modern assertive rhetorical tone are endless. See, for example, Kendal, Thanksgiving Sermon at 28-30 (cited in note 30).

11 Representative Murray, IV Annals of Cong 906 (Nov 25, 1794).

12 President Washington, IV Annals of Cong 796 (Nov 22, 1794).

${ }^{43}$ Alexander Addison, Necessity of Virtue in the People, $1 \mathrm{~Pa} 493-94$ (Sept 1795), quoted in Norman L. Rosenberg, Alexander Addison and the Pennsylvania Origins of Federalist First-Amendment Thought, $108 \mathrm{~Pa}$ Mag Hist and Biog 399, 407 (1984).

" Elijah Waterman, An Oration, Delivered Before the Society of Cincinnati, Hartford, July 4, 179418 (1794).

${ }^{45}$ Deodatus-No. II, Columbian Centinel 1 (Sept 27, 1794).

${ }^{46}$ An interesting parallel to their opinion regarding public affairs can be found in their attitude regarding private reputations. The Massachusetts Supreme Court reasoned that truth was not a defense

not ... because the law makes no distinction between truth and falsehood, but because the interest of the public requires, that men not invested with public authority by the laws, shall not usurp the power of public accusation, and arraign before the 
a democratic writer defended the clubs by arguing that they did and said only things that the Republican minority in the House of Representatives had done or said, a Federalist replied that this "furnishes no vindication for the conduct of the clubs ... [because] [t]here is an obvious distinction ... between a member elected by the people to discuss legislative matters and selfcreated and unauthorized clubs." ${ }^{.47}$

This view that one must be elected before one may criticize government-or even discuss public affairs-runs throughout Federalist commentary on their opponents. One Federalist journalist, for example, attacked the clubs for their audacity in presuming the "right of taking up and deciding upon all questions in which the people have an interest," and charged that they had the audacity "to criminate the President and other servants of the public, as if they had been created to office by the voice of their Clubs alone." ${ }^{\text {"48 }}$ The journalist suggested that if these club members had been elected "to office," their discussions and judgments of current affairs and their "criminations" against the president would have been legitimate. In the same vein, this journalist criticized the clubs for having "discussed and decided upon the same questions" as Congress. ${ }^{49}$ Another journalist, referring to the clubs, bluntly asked, "Are they legally elected to enquire into the conduct of public officers?"150 Yet another, speaking of "the common good ... or common-weal," said that "no man, or body of men, except such as be constitutionally appointed for the purpose by a majority of the whole people, can have a right exclusively to consult, act upon or direct [it]. ${ }^{151}$

public, with malicious motives, their neighbors and fellow citizens, exposing them to partial trials in forms not warranted by the constitution or laws.

Commonwealth $v$ Blanding, 20 Mass (3 Pick) 304, 312 (1825). One commentator suggested: "Under this theory, accusations were to be made solely to the government or other body that had the authority to deal with them. Thus, the court said complaints about a government officer should be made to the legislature and those against a minister to his church." Gibson, 55 Fordham L Rev at 287 n 148 (cited in note 8), citing Blanding, 20 Mass at 316-17.

${ }^{47}$ From a Correspondent, Gazette of the United States 2 (Dec 2, 1794).

${ }^{4}$ For the Columbian Centinel, Columbian Centinel 1 (Sept 27, 1794).

49 Id.

${ }^{50}$ A Friend to Republican Freedom, Gazette of the United States (Apr 10, 1794), quoted in Richard Buel, Jr., Securing the Revolution: Ideology in American Politics, 1789181599 (Cornell 1972).

${ }^{51}$ Order, Columbian Centinel 1 (Sept 3, 1794). Published complaints concerning the impropriety of meeting in clubs "to discuss national questions" are legion. See, for example, Anti-Club, Columbian Centinel 1 (Aug 27, 1794). 
This idea that only legislators enjoy full freedom to discuss public affairs can also be observed in a statement Congressman Harrison Gray Otis made during the House debates in 1798:

Can there be any necessity of allowing anonymous and irresponsible accusers to drag before the tribunal of public opinion, magistrates, and men in office, upon false and groundless charges? There are sixteen Legislatures in the United States, in which all the measures of Government are open to investigation. There are two Houses of Congress, in which every accusation and suspicion may have free vent, wherein our jealousies and prejudices may be uttered without restraint. $^{52}$

Otis clearly suggests that because the legislatures can investigate and discuss freely, there is no need for newspapers to do the same in a nonrepresentative environment. Federalist David Osgood expressed the same idea in a Thanksgiving Day sermon, where he asked, "are not the state legislatures fully competent to the business? Is not their interest at stake and their jealousy always awake, ready to notice any fault or error in the general government?"53 Another minister stated it most plainly, denouncing those "who wontonly undertake to decide upon the constitutionality of laws and treaties, when the constitution itself provides another tribunal for such trial and decision. ${ }^{34}$

${ }^{82}$ Representative Otis, VIII Annals of Cong 2150 (July 10, 1798).

${ }^{3}$ David Osgood, The Wonderful Works of GOD are to be remembered, A Sermon Deliv. ered on the day of Annual Thanksgiving, November 20, 1794, in Ellis Sandoz, ed, Political Sermons of the American Founding Era: 1730-1805 1219, 1232 (Liberty 1991) ("Thanksgiving Sermon").

${ }^{54}$ Packard, Federal Republicanism at 28 (cited in note 37). Federalist thinking, it should be added, was not just a question of attitude, but was reflected in the law. There were occasional prosecutions for seditious libel on the state as well as the federal level, based on both statute and common law. Reflecting the view that freedom of speech was nonetheless essential to the "deliberative process," members of the legislature enjoyed complete freedom from outside prosecution. Traditionally, the term "free speech" referred only to what legislators said in chambers. For example, the freedom of speech clauses appearing in colonial charters referred only to the freedom of legislators. Similarly, in Britain there was no mention of free speech in the Petition of Right (1628) or the Bill of Rights (1689). As late as 1780, the Massachusetts Declaration of Rights referred to the privileged nature of speech in the legislature without mentioning any popular right of free speech. See David S. Bogen, The Origins of Freedom of Speech and Press, 42 Md L Rev 429, 434 (1983). The reason for this, of course, was that legislators, not the people, were the ones deliberating. This idea is implicit in the comments John Randolph made to the Virginia House of Burgesses in 1736. Randolph said of the legislators that "Freedom of Speech is the very Essence of their Being, because, without it, nothing could be thoroly debated, nor could they be look'd upon as a Council." John Randolph's Speeches to the Virginia House of Burgesses, Governor and Council, Upon Being Chosen Speaker, August 5 and 6, 1736, in Michael Kammen, Deputyes and Libertyes: The Origins of Representative Government in Colonial America 195, 198 (Knopf 1969). 
It is in the context of their nonelective nature that the common epithet "self-created" can be understood. One Federalist queried, "Are they chosen by the people? If not, as I know no other authority, I shall hereafter regard them as self-creators." ${ }^{35}$ Another manifestation of this idea was to criticize the clubs for not having any legal foundation. Deliberation, after all, should occur through the formally established processes of representation. As Noah Webster put it, only those "directly authorized by the Constitution and laws" should exert "influence" in a state. ${ }^{56}$ The clubs, however, were "unauthorized by the laws"; 57 they were "unfounded and unknown to our Constitution and Laws. ${ }^{58}$ The Federalists wanted to know what right the Democrats had "to organize themselves into self-constituted authorities, unknown to the constitution."59 They resolved that the nation should "never suffer an external influence, unknown to the laws of our country, to interpose and warp its administration.".60

To say that only elected officials should criticize officials and policy and in other ways guide the affairs of nation is to say that when others try to do the same, they are usurping an authority that was actually bestowed on others. Charges to this effect thickly dot the literature of the 1790s. A columnist writing for the Gazette of the United States, for example, complained that through their political agitation and organization the clubs were "usurping the station assigned to the representatives of their country constitutionally chosen." ${ }^{\prime 1}$ Another journalist claimed that the clubs were "invad[ing] the rights or [ ] seiz[ing] upon the powers of the constituted authorities of the people."122

Because it demonstrates that their problem with the clubs concerned how representation was conceived, it is revealing in this context that Federalists specifically used the word "delegation." One orator, for example, referring to radical efforts to mobilize support, said to the public, "and you, yes, you, my countrymen, [have] been incited to plunder your constituted authorities

\footnotetext{
${ }^{55}$ A Friend to Good Government, New York Daily Gazette (Feb 21, 1794), quoted in Foner, ed, A Documentary Sourcebook at 154 (cited in note 23).

${ }^{56}$ Noah Webster, Letter to Joseph Priestly, III (Jan 20, 1800), in Harry R. Warfel, ed, Letters of Noah Webster 207, 208 (Library 1953).

${ }^{57}$ Osgood, Thanksgiving Sermon at 1232 (cited in note 53).

${ }^{58}$ For the Columbian Centinel, Columbian Centinel 1 (Sept 27, 1794). See also Osgood, Thanksgiving Sermon at 1229 (cited in note 53) (denouncing "[p]opular societies, unknown to the laws").

${ }^{59}$ Anti-Club, Columbian Centinel 1 (Aug 27, 1794).

${ }^{\circ}$ Noah Webster, An Oration Pronounced before the Citizens of New Haven ... July 4, 179814 (T \& S Green 1798).

${ }^{61}$ Marcellus-No. I, Gazette of the United States 1 (Nov 20, 1794).

${ }^{62}$ Communications, Columbian Centinel 2 (Oct 1, 1794).
} 
of your choicest delegated powers. ${ }^{\text {"63 }}$ A congressman asserted that the clubs were trying "to usurp a power which the people never delegated to them." Justifying the charge of usurpation, Hezekiah Packard, a Federalist minister, explained "that citizens have a place and a sphere in which to act as well as their rulers," and there are "constitutional bounds and fences to prevent not only our rulers from encroaching upon the rights of citizens, but also to prevent citizens from encroaching upon the delegated rights and powers of their rulers. ${ }^{.65}$

The fact that society has delegated certain functions to its agents implies that when others infringe on these functions, they are not only usurping the delegated rights of these agents, but the rights of the delegating principals as well. The people, after all, have delegated these powers to their officials, and not to the clubs and opposition press. One Federalist, for example, stated that by engaging in the kind of political activities they had, the radicals had "arrogated to themselves rights, which do and can alone belong to society at large. ${ }^{166}$ Another similarly concluded that the clubs were "shameless usurpers of the rights of society." A third wondered "what presumption then is it, and what an usurpation of the rights of their brethren, for private associations, unauthorized by the laws, to arrogate this charge to themselves?"68

If the Federalists' arguments sound odd, it need only be remembered that to them the "public" nature of public discussion meant that this discussion was "public" not in the sense of the village commons, open to all, but of a military base. The people own it but this does not mean individuals can traverse it at will. On this point a journalist denied the democratic claim that the clubs and opposition press enjoyed the right of unfettered free discussion and agitation because they were part of the "people." In regards to their "public" discussions of "the measures and men" involved in national affairs, he pointed out:

As well might a band of midnight Robbers stile themselves the people, and seize upon the public treasure, under pretense of its being the people's property. The band would ap-

\footnotetext{
« Josiah Quincy, An Oration, Pronounced July 4, 1798, at the Request of the Inhabitants of the Town of Boston, in commemoration of the Anniversary of American Independence 28 (Boston 1798).

${ }^{64}$ Representative Dexter, IV Annals of Cong 938 (Nov 27, 1794).

${ }_{65}$ Packard, Federal Republicanism at 27-28 (cited in note 37).

${ }^{65}$ For the Columbian Centinel, Columbian Centinel 1 (Sept 27, 1794).

${ }^{67}$ Marcellus-No. I, Gazette of the United States 1 (Nov 20, 1794).

${ }^{68}$ Osgood, Thanksgiving Sermon at 1232 (cited in note 53).
} 
pear less criminal and dangerous, before any tribunal, than the Clubs; for the former will have robbed the community only of its wealth; but the latter destroy also its peace, its safety and happiness. ${ }^{69}$

Federalist theory also found expression in the charge that opposition to government was a traitorous attempt to defeat the will of the people. This assertion followed logically from the fact that the will of the people, complete and entire, is "re-present" in the will of the representatives. As one Federalist states, "the Administration, is, of necessity, elected by a majority of the peopletheir proceedings are voluntarily approbated by a majority of the people, and their measures are authorized by a majority of themselves. ... It is patriotism to write in favor of our government-it is sedition to write against it." ${ }^{70}$ Revealing the same set of assumptions, another Federalist said, speaking of the opposition's vigorous criticism of the "government," that "every violent attack, therefore, may be concluded to proceed from a conscious opposition to the will of the majority." 11

Because their disagreements with the radicals were conceptual, not just political, the Federalists believed they perceived intellectual inconsistencies in the radical position. One of the most revealing of these is the accusation that by directly participating in a process in which representatives were also engaged on their behalf, the clubs were inconsistently both delegating and exercising the same power at the same time. A Federalist minister, for example, said, "we reprobate the inconsistent idea of power, delegated to the rulers, remaining, at the same time, in the hands of the people, ${ }^{\prime 2}$ and a journalist, reiterating this idea, stated that

* For the Columbian Centinel, Columbian Centinel 1 (Sept 27, 1794).

${ }^{70}$ Albany Centinel 1 (Oct 12, 1798). See also Representative Dexter, IV Annals of Cong 937-38 (Nov 27, 1794) ("The clubs have waged war not only with the Government which the people have instituted and the rulers which they have appointed, but they have counteracted all the most essential principles of Republicanism. They, being a small minority, have attempted to control the majority.").

${ }^{71}$ Kendal, Thanksgiving Sermon at 19 (cited in note 30). A writer for the New York Gazette explained that while opposition to a government not founded on the people's will can be justified in democratic terms, opposition to a "really legitimate government is treason against the People," and cannot be justified. New York Gazette and General Advertiser (Nov 13, 1798), quoted in Smith, Freedom's Fetters at 179 (cited in note 14). This opinion was seconded by a writer for the Columbian Centinal who said that when people have a representative government, "it is treason against the majority of the people for a small number connecting themselves together by the title of Democrats, Jacobins, or any other term, to attempt to deprive the REPRESENTATIVES of the PEOPLE of the authority legally and voluntarily delegated to them." Mortimer, Columbian Centinel 1 (Oct 18, 1794).

${ }^{72}$ John Mellen, A Sermon Delivered before his Excellency the Governor, and the Honourable Legislature, of the Commonwealth of Massachusetts, on the Annual Election: May 31, 
"the idea of delegating power, and reserving the right to exercise it, is too absurd to be for a moment entertained by any but such as chiefly compose our Jacobin Societies."73

Other absurdities followed from the radical position. Since they were engaged in what had been thought a governmental process, the radicals were accused of trying to establish a second "government," of trying to "legislate," and of trying to occupy public "office[s]" or to "overrule" officials. ${ }^{74}$

These absurdities suggest overlapping functions, and this idea is also inherent in the Federalist assertion that the people must "choose" between rule by the clubs or by the legislature. ${ }^{75}$ When two entities occupy the same position, by implication, one of them is unnecessary. Hence, Federalists spoke of the "inutility and danger of such societies," because the nation already possessed an "immense body of public functionaries, who . . . are elected ... [and serve] adequate[ly] as functionaries to the public purposes of the country." This idea of redundancy is also implicit in the Federalist argument that, while popular political organizations might be necessary under a despotic government, they were completely unnecessary under the Federalists' representative government. ${ }^{77}$

It is impossible to understand the radical nature of the Federalist alternative to modern democracy unless it is fully grasped that they specifically identified and rejected the chief institutional and conceptual features of modern democracy. Modern

1797 20-21 (Boston 1797) ("Election Sermon").

${ }^{73}$ Order, Columbian Centinel 1 (Sept 3, 1794).

"For an example of "government," see Marcellus-No. I, Gazette of the United States (Nov 20, 1794). For an example of "legislate," see Tammany Society, To the People of the United States Approving of the Conduct of the President of the United States, January 19, 1795, in NY J (Jan 21, 1795), republished in Foner, ed, A Documentary Sourcebook 205, 207 (cited in note 23). For an example of "office," see Representative Dexter, IV Annals of Cong 938 (Nov 27, 1794). For an example of "overrule," which of course implies that the clubs presume to hold some legal office, see Anti-Club, Columbian Centinel 1 (Aug 27, 1794). In modern democracy, of course, we say we oppose or disagree with government; "overruling" has nothing to do with it.

${ }^{76}$ Deodatus-No. I, Columbian Centinel 4 (Sept 13, 1794).

${ }^{76}$ Representative Murray, IV Annals of Cong 906-07 (Nov 25, 1794).

"As Representative Dexter said, "Such societies are proper in a country where Government is despotic, but it is improper that such societies should exist in a free country like the United States." IV Annals of Cong 910 (Nov 25, 1794). Many others voiced identical sentiments. A minister, speaking of the "American Committees of Safety" that existed during the revolution, explained that extra-legal organizations were appropriate then because Americans were living under repressive British rule, "but when a free government of their own choice was established and put into operation ...., these associations were no longer needful or safe." David Tappan, Christian Thankfulness Explained and Enforced 36 (Samuel Hall 1795). See also Daniel Davis, An Oration, Delivered at Portland, July 4, 1796 14-15 (Portland 1796) (expressing the same distinction). 
democratic theory embraces "intermediate" organizations for their role in enabling the people to aggregate and develop public opinion directly by standing between and mediating the relations between citizen and government. ${ }^{78}$ The Federalists could not disagree more. One Federalist, for example, challenged the clubs, asking, "Do the people require intermediary guides betwixt them and the constituted authorities?"79 Another complained that the clubs "set themselves up as umpires between the people and the government," which he abhorred since he was against "any intermediate power or body . . . between the people and their representatives. ${ }^{180}$ Similarly, the efforts at public persuasion inherent in the modern system, because they imposed the new burden on the people, that of deciding political questions, were perceived not as a necessary part of a democratic system, but as invasions of the citizen's privacy. The Federalists perceived the radicals as "tyranniz[ing] over the political opinions of their fellow citizens." The purpose of persuading others, of course, is to aggregate electoral strength in blocks and this too was denounced. Pointing to the power these aggregations would take from their representatives, the Federalists repeatedly emphasized that, politically speaking, individuals should operate not as organized groups but only in terms of "their individual capacities."

${ }^{78}$ According to one author, there is a general consensus that "democracy presupposes the backbone of an 'intermediate structure' of independent groups and voluntary associations." Giovanni Sartori, Democracy, in David L. Sills, ed, International Encyclopedia of the Social Sciences 119 (Macmillan 1968), citing William Kornhauser, The Politics of Mass Society (Free 1959). These institutions form a large component of what is now referred to as "civil society." The latter has sometimes been defined as all the political institutions and activities that fall short of "government."

${ }^{79}$ A Friend to Good Government, New York Daily Gazette (Feb 21, 1794), in Foner, ed, A Documentary Sourcebook at 154 (cited in note 23).

${ }^{80}$ E.F., Gazette of the United States (July 21, 1794). See also A Citizen, New York Daily Gazette (Aug 4, 1794), quoted in Buel, Securing the Revolution at 99 (cited in note 50).

${ }^{81}$ Marcellus-No. I, Gazette of the United States 2 (Nov 20, 1794). The author went on to say that they were an "effrontery" because they were attempting "to dictate opinions to the community." Id. Another Federalist, referring to Washington's Proclamation of Neutrality, stated that clubs "impudently obtruded upon the public, their own opinions on" political questions. For the Columbian Centinel, Columbian Centinel 1 (Sept 27, 1794).

82 Fisher Ames, for example, noted that "[i]t is obvious, that the combination of some hundreds or thousands for political ends will produce a great aggregate stock or mass of power." Fisher Ames, The Dangers of American Liberty (Boston 1805), in Charles S. Hyneman and Donald S. Lutz, eds, 2 American Political Writings during the Founding Era, 17601805 1299, 1320 (Liberty 1983). See also Deodatus-No. II, Columbian Centinel 1 (Sept 27, 1794) ("Men should judge for themselves and not pin their faith on the vote of a club, as if a parcel of men could throw their real private opinions into a common flock and think as the major vote may direct."); Osgood, Thanksgiving Sermon at 28 (cited in note 53) (arguing that citizens should participate in the political process as individuals, not as groups); Rosenberg, $108 \mathrm{~Pa}$ Mag Hist and Biog at 407 (cited in note 43) (discussing Alexander Addison's view that "collective social movements" were bad, whereas the "convergence of individual actions" 
Underlying the Federalist rejection of modern democratic processes was a corresponding rejection of the conceptual framework that gave these processes meaning. The modern system encourages the idea of a public continuously involved in the political process through constant direct deliberation. ${ }^{83}$ Because the Federalists believed that the public had delegated the task of deliberation, however, they concluded that the public should normally be absent from the daily political process. This is what lies behind Madison's comment that "[t]he true distinction between [ancient Greek democracies] and the American government, lies in the total exclusion of the people in their collective capacity, from any share in the latter." ${ }^{\text {"84 }}$ Reflected in this absence is a rejection of the modern idea, elaborated upon by many democratic theorists, that the locus of decisionmaking power resides in "civil society" and that government is popularly "controlled" in this way. One Federalist commented that while those of his persuasion

wishe[d] . . . all men, to be subject to the . . . public will, expressed by the constitutional legislature . . . [a] Democrat wishes and endeavors to govern the country by small parties and private clubs ... and, in short, to put in the power of private cabals and occasional popular meetings to govern the constitutional government. ${ }^{85}$

Believing that the decisionmaking role of elected officials should be respected, the Federalists criticized the "external control" wielded by clubs. They condemned the radicals for their "at-

was good). The Federalists, in short, were against what one historian called "collective social movements." Rosenberg, $108 \mathrm{~Pa}$ Mag Hist and Biog at 407.

${ }^{3}$ See, for example, Eileen Lorenzi McDonagh, Representative Democracy and State Building in the Progressive Era, 86 Am Pol Sci Rev 938 (1992) (describing the modern view as claiming that "citizens continuously have 'a form of indirect access to public policy making,' exerting pressure both at the point of elections and throughout terms of office”).

s Federalist 63 (Madison), in Clinton Rossiter, ed, The Federalist Papers 382, 387 (Mentor 1961). Though affiliated with Jefferson, Madison retained a Federalist's fear of popular involvement in the political process until the day he died. See Drew R. McCoy, The Last of the Fathers: James Madison and the Republican Legacy 116-17 (Cambridge 1989).

${ }^{*}$ Distinctions between a Republican and a Democrat of the Present Day, Columbian Centinel 3 (Sept 13, 1794). Hamilton also explained: "[A]ll combinations and associations under whatever plausible character with the real design to sdirect counteract controul influence or awe the regular sdeliberation or action of the constituted authorities are contrary to

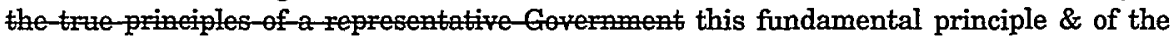
most dangereus fatal tendency." Alexander Hamilton, Letter to George Washington containing Hamilton's draft of Washington's Farewell Address, July 30, 1796, in Morton J. Frisch, ed, Selected Writings and Speeches of Alexander Hamilton 430, 439 (Am Enterprise Inst 1985) (drafting notes in original). This idea is also implicit in the Federalist claim that these clubs constitute "a chain of political systematic associations, whose object is to control the elections and measures of our rulers." Tappan, Christian Thankfulness at 22-23 $\mathrm{n}$ * (cited in note 77). 
tempt to overawe the government," the councils of our country, to rob them of their energy, and deprive them of their power." ${ }^{287}$ Complaining that the DemocraticRepublicans "wish[ed] to controul the constituted authorities," and that their "professed design is the superintendance of . . . government," the Federalists concluded that "[i]n every aspect of the discussion, the societies formed to control ... a Republican Government are hateful." ${ }^{\prime 90}$ After a hostile description of the radical conception of the political process, one Federalist asked facetiously, "[I]s this democracy?"91 The modern answer would, of course, be yes.

The Federalist ideal was for elected officials to be immune from the influence of organized factions. One Federalist writer went so far as to say that government would not be safe "until the legislative body is set totally above the influence of a surrounding populace."92

Importantly, because the Federalists believed external control violated the principles of representation, they also believed it violated the principles of the Constitution. They rejected the radicals' contention that private political organizations could be one of the "checks and balances" in the Constitution. One Federalist declared that these "checks and balances . . . are not only unknown to the Constitution but altogether repugnant to it. ${ }^{.93}$ Noah Webster, an arch-deacon of Federalism, seconded this notion: "If that system of creating a popular interest extraneous from the legislature to influence their proceedings-that system of raising a multitude of isolated private clubs over the nation as its guardians-should spread thro the country, we may bid adieu to our Constitution. ${ }^{.94}$

B. Duty to Support Representatives and the Government

While the restrictive manifestations of Federalist democratic theory, such as the Sedition Act, have received extraordinary

\footnotetext{
${ }^{86}$ Manlius No. V, Columbian Centinel 1 (Sept 17, 1794).

${ }^{87}$ John Wells, An Oration Delivered on the Fourth of July, 179813 (MLean and Lang 1798).

Communication, Columbian Centinel 3 (Aug 27, 1794).

* To the Vigil, Gazette of the United States 2 (Dec 6, 1794).

${ }^{90}$ Representative Ames, IV Annals of Cong 925 (Nov 26, 1794).

${ }^{91}$ Anti-Club, Columbian Centinel 1 (Aug 27, 1794).

${ }^{2}$ Revolution in France, Gazette of the United States 2 (Nov 13, 1794). See also Buel, Securing the Revolution at $99 \mathrm{n} 20$ (cited in note 50 ).

${ }^{93}$ Communication, Columbian Centinel 3 (Aug 27, 1794).

*4 Webster, Letter to Theodore Sedgewick (Jan 2, 1795), in Warfel, ed, Letters of Noah Webster 124, 125 (cited in note 56).
} 
amounts of attention, their corresponding positive duties have been largely ignored. But the historical record is clear that the Federalists expected the people not only to refrain from engaging in public deliberation, but also to support the results produced by their elected representatives. This requirement of support for government actions underlies the Sedition Act.

The theory behind the Federalist position is a straightforward application of "separateness" and "identity" to the process of deliberation. The Federalists held that the people elected representatives to deliberate on their behalf. Since deliberation involves developing and creating a public will, it would therefore be self-contradictory for the people to deny support and respect for the representatives and their decisions. Just as the modern citizenry, by refraining from legislating and by obeying laws, maintains the representative fiction that the laws are theirs, the Federalist citizenry, through respect and support, maintains the representative fiction that the pronouncements and policies of government are theirs. In both cases the agent's actions and principal's behavior correspond.

Federalist literature repeatedly argued that the obligation to support and respect followed logically from the fact of election. In response to the opposition press and the clubs, the Federalists stressed time and time again that Americans must support their government because they chose it. ${ }^{95}$ One Federalist explained

${ }_{95}$ Even a small review of the literature of the period will reveal innumerable citations to the effect that the public is obligated to support and respect the officials it elects. See, for example, Address of the Society of Cincinnati of the Commonwealth of Massachusetts to the President of the United States, Columbian Centinel 1 (July 25, 1798) ("To respect the laws and support the government of our country, were among the first principles with which we retired from the field of our revolutionary war."); Celebration of Independence, Albany Centinel 1 (July 17, 1798) ("May the reciprocal confidence of the Government in the people, and the people in their Government never be misplaced."); Embassy of Mr. Monroe, Albany Centinel 3 (Aug 31, 1798) ("I will therefore add my political creed-that I respect and will, to my utmost, support the Chief Magistrate of the Union . . . . That I will ever and cheerfully obey the Laws of the United States and of every State where I may reside or sojourn; and will never calumniate any Senator, Representative, Minister, Civil or Military Officer."); Nathanael Emmons, A Discourse delivered on the National Fast (Wrentham 1799), in Hyneman and Lutz, eds, 2 American Political Writings 1023, 1028 (cited in note 82) ("It is the duty of civil magistrates to seek the general welfare of the people, and so long as they diligently and faithfully attend upon this very thing, they justly merit the obedience and concurrence of every one of their subjects. For every person ought to desire, and as far as he can, contribute to the peace and prosperity of that community to which he belongs. Let a civil constitution be ever so good, it can answer no valuable purpose, unless the people will submit to those in administration. Rulers are mere cyphers, without the aid and concurrence of their subjects."); Charles Lee, Defence of the Alien and Sedition Laws 46 (Fenno 1798) (Let us not listen to the agitators scattered through the country, busy in deceiving, busy in alarming, busy in exciting the people against their own laws and their own law givers.") ("[A]nd respecting [the Alien and Sedition Act's] necessity or expediency, that you will confide in the wisdom 
that "at all times it is a duty [to support] the government of your choice." ${ }^{\text {"96 }}$ Another assured President Adams in a petition that the undersigned were "[f]ully impressed with a sense of the importance of confiding in rulers of our own choice. ${ }^{97}$ In a piece denouncing the "Jacobin clubs," one orator stated, "Our rulers are chosen from among us. ... . [S] Thall we then hesitate to confide in their wisdom, and to abide by their counsels[?]"98 Another Federalist told the people, "You feel and know that a just and entire confidence in the government appointed by yourselves, is as necessary to your liberty as to your peace." ${ }^{\prime 99}$ Worried about the effects of the clubs and opposition press, he added, "distrust the counsel, and repel the influence, that would divide you from the government, which you yourselves have formed for your own protection and happiness." 100

To support also implies respect. As one Federalist put it, "[T] he people are . . . accustomed . . . to choose their Representatives, to respect them when chosen, to place confidence in them, and obey their laws." 101 Another expressed a similar idea when he said, "Obedience to the laws, and a venerable respect for those delegated by the people to enact them, is . . a first principle with real Republicans." 102

As one Federalist explained, pointing to the principle of representation involved: "In a country where all authority originates

and patriotism of the national legislature, the supreme councils of our country, to whom by our free suffrages are committed our political existence and safety."); Stephen Peabody, Sermon before the General Court of New Hampshire at the Annual Election (1797), in Sandoz, ed, Political Sermons 1323, 1333-34 (cited in note 53) ("How important, then, that [free government] should be supported; that every aid should be given to those who are entrusted with authority, so long as they perform their duty.... An opposition to good government is inexcusable, as it 'resists an ordinance of God."'); William Tudor (the elder, of Boston), $A$ Gratulatory Address, Delivered July 5th, 1790, before the Society of the Cincinnati, of the Commonwealth of Massachusetts 11 (Benjamin Russell 1790) (admonishing that "with caution elect, but the delegation once committed, let us not with-hold a generous confidence in our Rulers").

The corollary of exhorting people to support the government is, of course, condemning those who oppose it. See, for example, Marcus Brutus, Sixth Letter on the Politics of the Day, Albany Centinel (June 12, 1798) (denouncing Irish immigrants who had "join[ed] the factions of your country, and disturb[ed] the peace of the people by turbulent and seditious harangues").

${ }^{96}$ Leonidas, Columbian Centinel 2 (July 18, 1798).

${ }^{97}$ To the President of the United States, an address from Cambridge, Mass., Columbian Centinel 2 (June 2, 1798).

${ }^{9}$ Waterman, An Oration at 18 (cited in note 44).

${ }^{99}$ Marcus Brutus, Letters on the Politics of the Day, Addressed to the People, Albany Centinel 1 (May 25, 1798).

${ }^{100} \mathrm{Id}$.

${ }^{101}$ Webster, Letter to Joseph Priestly, III at 208-09 (cited in note 56).

${ }^{102}$ Communications, Columbian Centinel 2 (Oct 1, 1794). 
from the people, it is rebellion against ourselves . . to bring our rulers into contempt. . . . [Instead of contempt,] honor is due to the framers and administrators of the laws." 103 Another Federalist made the same point. He said: "SUBORDINATION, so obnoxious to some of the feelings of the human heart, is here qualified by a consciousness, that ... a deference for our rulers, is no other than respect for ourselves." 104

Yet another said that "the keenest of all insults against the people is that, which holds up its representatives to dishonor."105 Abigail Adams reflected these same assumptions when she complained that the Jacobin commentaries, by insulting the government, were also insulting "the Majesty of the Sovereign People. ${ }^{106}$ A Federalist newspaper argued that by "indiscriminately defaming the Legislature and Administration ... [the opposition was] openly vilifying that very PEOPLE for whom they profess so deep a respect. ${ }^{107}$

An interesting implication of this obligation to support and respect the government was that it applied no matter what the government's policies were. Just as today a citizen-whether or not he agrees with a particular law-is called upon to obey it as the legitimate and exclusive expression of the people's will, the Federalist citizen was called upon to defend the exclusive right of elected officials to decide political questions and speak for the nation, regardless of his personal feelings about the government actions in question. Timothy Dwight, President of Yale University, explained this in a sermon in 1798. He said that among "good citizens,"

adherence to our government ... may be regarded as a thing of course. They need not be informed, that the existing rulers must be the directors of our public affairs, and the only directors; that their views and measures will not and cannot

\footnotetext{
${ }^{103}$ James Freeman, A Sermon for December 15, 1796; The Day of Public Thanksgiving 16 (William Spotswood 1796).

${ }^{104}$ Oliver Fiske, An Oration, Pronounced at Worcester, on the Anniversary of American Independence; July 4, 17975 (Isaiah Thomas 1797).

${ }^{105}$ Quincy, An Oration at 21-22 (cited in note 63).

${ }^{106}$ Abigail Adams, Letter to Mary Cranch, Philadelphia, April 26, 1798, quoted in Smith, Freedom's Fetters at 97 (cited in note 14).

${ }^{107}$ New York Gazette and General Advertiser (Nov 13, 1798), quoted in Smith, Freedom's Fetters at 179 (cited in note 14). See also Mellen, Election Sermon at 27 (cited in note 72) ("Permit me to observe, that such a kind of confidence, as has been recommended, may, with peculiar justice, be expected of the subjects of such a government as our own, in which all the rulers are, either directly or indirectly, appointed by the people: Since, in censuring them we do, in some measure, cast a reflection on our own, or at least, the public wisdom or integrity."); Norman L. Rosenberg, Protecting the Best Men: An Interpretive History of the Law of Libel 72 (UNC 1986).
} 
always accord with the judgement of individuals, as the opinions of individuals accord no better with each other. . . . [Nevertheless,] the government ought, especially in great measures, to be as secure, as may be, of the harmonious and cheerful co-operation of the citizens. All success, here, depends on the hearty concurrence of the community. ${ }^{108}$

A similar idea was expressed in a 1797 election sermon, where the minister stated that a citizen,

whatever his sentiments may be on disputed political questions, will, we may expect, quietly yield up private opinion to that of the public, as expressed by the constituted organs of the general voice; so far at least, as to submit, without difficulty or opposition, to its established effects. ${ }^{109}$

Another minister seconded this idea. He said:

Let there be therefore ever so great a diversity of opinion in the Legislature itself, or among the body of the nation, respecting the expediency of [government] measures; when they are once enacted by a constitutional majority of the Legislature, receive the signature of the Supreme Executive, and become the Laws of the land; it is incumbent on the citizens to support them. ${ }^{110}$

Alexander Hamilton concurred. Speaking of the government, he said, "Respect for its authority, compliance with its laws, acquiescence in its measures, are duties dictated by the fundamental maxims of true Liberty."111

What distinguishes Hamilton's statement from one a modern commentator might make is the part about "acquiescing." Today, of course, as two hundred years ago, the people are obligated to "comply" with the laws because they have delegated to others the right to pass them. At this earlier time, however, they were additionally obligated to "acquiesce," in the sense of not opposing government policy, regardless of personal opinion because the policymaking process had also been delegated.

The obligation to support one's officials in their deliberative capacity effectively confounds any distinction between obeying

\footnotetext{
${ }^{108}$ Timothy Dwight, The Duty of Americans, at the Present Crisis (1798), in Sandoz, ed, Political Sermons 1367, 1386 (cited in note 53).

${ }^{109}$ Mellen, Election Sermon at 27-28 (cited in note 72).

${ }^{110}$ Abiel Holmes, A Sermon Preached at Brattle-Street Church, in Boston, and at Cambridge, April 25, 1799, The Day Appointed by the President of the United States for a National Fast 22 (Young \& Minns 1799) ("National Fast").

${ }^{111}$ Hamilton, Letter to George Washington at 439 (cited in note 85).
} 
the laws and obeying the lawmakers. This is because, unlike the modern citizen, who is only called upon to support the laws, the Federalist citizen must also support what led up to and lies behind the laws, that is to say, the policies, viewpoints, and utterances of elected officials. Not making any distinction between satisfying the legally binding requirements of law and acquiescing to the leadership of those in public office, one Federalist defined "[t]he characteristics of a good citizen" as "obedience to the laws, and submission to the constituted authorities."112 For another, the obligation to support leaders blurred the distinction between following Congress's laws and following its advice. He said the good citizen should not "resist or contravene, but . . . pay implicit obedience to the acts and even the recommendations of Congress." ernments," explained the rationale behind this attitude:

Every people either directly or indirectly promise submission to their rulers. Those, who choose their civil magistrates, do voluntarily pledge their obedience . . . . By putting power into the hands of their rulers, they put it out of their own; by choosing and authorizing them to govern, they practically declare, that they are willing to be governed; and by declaring their willingness to be governed, they equally declare their intention and readiness to obey. ... The subjects of every elective government, therefore, voluntarily and expressly engage to obey those, whom they raise to places of power and trust. ${ }^{114}$

The author assumes that when people elect officials, they are not only choosing people to pass and enforce laws for them, but are selecting men to lead and direct society; consequently, the obligation to accept their leadership is as strong as that to obey any resulting laws.

By inextricably combining the idea of obeying the law with that of cooperating with the lawmaker, delegation of the deliberative process blurs or erases completely the distinction between legal and illegal opposition to the law. When farmers in western Pennsylvania, for example, said they were going to use every "legal measure" at their disposal to "obstruct" the collection of the whisky tax, Alexander Hamilton rejected their claim as "a con-

${ }^{112}$ This was part of a toast given at an Independence Day celebration in Albany, New York. See The Twenty-Third Anniversary of American Independence, Albany Centinel 3 (July $6,1798)$.

${ }^{113}$ A Federalist, For the Albany Centinel, Albany Centinel 3 (June 29, 1798).

${ }^{114}$ Emmons, Discourse at 1027 (cited in note 95). 
tradiction in terms."115 In Hamilton's mind, the farmers were as obligated to support the intentions of their governors as they were to support the letter of the law. He thus considered what would now be viewed as perfectly legal democratic opposition as ipso facto evidence of sedition.

By the same pattern of thinking, the duty of support is a constitutional one. Because the obligation to support government is inherent in representation, and because the United States and individual state constitutions established representative forms of government, support is constitutionally prescribed. A writer investigating "[t]he principles of our constitutions" and "the spirit of our government, as a free representative republic," said as much when he asked: "Is not the essence of our government representation? Does it not result from this ... [that] our public functionaries ... are entitled to a large and liberal confidence?"116

Another author, writing under the name "Marcus Brutus," made a similar point. "[A]ppeal[ing] to the spirit of the constitution [and] the forms it prescribes," and denouncing "the false and disastrous principle, that the American people, to be free, must be jealous of their rulers," he stated that we should "engage our confidence in the government of our choice."117 The type of support expected was illustrated by the legislature of New York, which, speaking of "the Constitution of the United States," said that since the "government" is "being administered by men constitutionally chosen and appointed, [it] shall, in all its constitutional and legal proceedings, receive our decided support."118

Under this conception, it is clear that opposition to the policies of the government was tantamount to opposing both representative government and the Constitution itself. ${ }^{119}$ One Federalist, for example, condemned the clubs' avowal of the modern idea of a legitimate opposition and reiterated the Federalist belief that representative government necessitated support. Speaking of a "democrat," he said: "Let him not deceive himself by saying

\footnotetext{
${ }^{115}$ Alexander Hamilton, Letter to John Jay (Sept 3, 1792), in Harold C. Syrett, et al, eds, 12 The Papers of Alexander Hamilton 316 (Columbia 1967).

${ }^{116}$ Communication, Albany Centinel 3 (June 8, 1798).

${ }^{117}$ Marcus Brutus, Second Letter on the Politics of the Day, Addressed to the People, Albany Centinel 1 (May 29, 1798).

${ }^{118}$ Address of the Legislature of New-York, to the President of the United States, Albany Centinel 1-2 (Aug 28, 1798).

${ }^{119}$ Using the Old Testament's King David as an analogy, Samuel Kendal argues that attacks on the leader of the nation, "in his official capacity," are really "levelled against the government itself." Kendal, Thanksgiving Sermon at 6 (cited in note 30). See also Tappan, Christian Thankfulness at 24 (cited in note 77) (specifically identifying attacks on the administration of government with attacks on the Constitution).
} 
that he is for his country, but opposed to its government, or that he is for the government, but opposed to its administration, or that being opposed to all, he is still a republican." ${ }^{120}$ Representative government, in this writer's opinion, meant citizens should display "manly, and even unbounded confidence in those whom the people had chosen to act for them," and should "support their tried and approved servants." 121

This was by no means an isolated opinion. Throughout Federalist literature, the obligation to support the laws and constitution of the country was consistently confounded with the obligation to support the current administration. Most commonly, Federalists charged that democratic criticisms of the administration were inconsistent with their claim to support the Constitution and representative government. One Federalist commented that the "Republican boasts of his regard to the Federal Constitution and federal government, yet finds fault with every law and every act of that government."122

Sedition, being most fundamentally the refusal to cede elected officials their right to determine the political course of the nation, is just the enforcement side of the obligation to support. Charles Lee, by mentioning a legally enforceable obligation to "assist" and "respect," implicitly defined the term this way in his Defence of the Alien and Sedition Laws. ${ }^{123}$ Here he asserted that "the chief magistrate ... should be respected and assisted by all the citizens, and to oppose or hinder him in the due course of discharging his duties, is an offence punishable at common law."124 This same point was made by another Federalist who clarified the democratic foundations of sedition laws. He sarcastically noted that "our mock patriots adopt the absurd, and dangerous idea, that to serve the people, they must be eternally contending with their government.-This, in countries of despotic sway, may indicate true patriotism: but in ours, where the constitution is sanctioned by the voluntary consent of the people, it wears the genuine features of sedition and treason." ${ }^{125}$ Ironically, then, sedition was something that could only be considered a crime in representative governments.

${ }^{120}$ A Federalist, For the Albany Centinel, Albany Centinel 3 (June 29, 1798).

${ }^{121} \mathrm{Id}$.

${ }^{122}$ Communications, Columbian Centinel 2 (Oct 15, 1794). See also A Lover of Consistency, Columbian Centinel 2 (Oct 4, 1794) (claiming that the Jacobins were inconsistent when they defended the Constitution yet attacked the administration).

${ }^{23}$ Lee, Defence of the Alien and Sedition Laws at 20 (cited in note 95).

${ }^{124}$ Id at 21.

${ }^{125}$ Daniel Davis, An Oration, Delivered at Portland, July 4, 179615 (Portland 1796). 
In the ultimate analysis, the Federalists believed that government would come to an end if the policies and expressions of government were not respected, just as the modern citizen believes that government will perish if no one obeys the laws. According to some Federalists, those trying to undermine the confidence of the people in their government "must meditate the destruction of all free government."126 Responding to the same threat, Governor Sumner of Massachusetts remarked that "whoever attempts to divide [the people from their government], cannot be viewed in any other light, than as aiming a blow at the main pillar, on which the whole superstructure rests." ${ }^{.27}$ Justice Iredell charged a grand jury: "Take away from a Republic the confidence of the people, and the whole fabric crumbles into dust." "28 A minister similarly charged his congregants, "When such support is refused, there is the end of all free and regular government." 129

This perceived absolute need to maintain agreement between the people and their "re-presentations" led Federalists to construct an ideal citizen that was almost the opposite of the modern one. Whereas the modern ideal citizen is contentious and active, ready to oppose those in authority if he disagrees about the issues, the Federalist citizen obediently supports his administration. ${ }^{130}$ As one Federalist said: "If you love your country, you will of course ... adhere to the principles of our national government, and follow like good citizens, the general current of administration."131

In the Federalist view, members of the public should behave in a manner that a modern person might call docile. Speaking of citizens, one Federalist said that "they pay an orderly and respectful regard to the laws and regulations of government; and ... will place confidence in their public officers, and submit their public concerns with cheerfulness and readiness, to the decisions and determinations of Congress and their own Legislatures."132

\footnotetext{
${ }^{126}$ Answer of the House to the Governor's Address, Albany Centinel 1 (June 22, 1798).

${ }^{127}$ The Genuine Spirit of '76, Unadulterated, UnFrenchified: Governor Sumner's Speech to the Legislature of Massachusetts, Albany Centinel 3 (June 19, 1798).

${ }^{128}$ James Iredell, $A$ Charge, Delivered to the Grand Jury for the District of Pennsylvania, in the Circuit Court of the United States for the said District, held in the city of Philadelphia, April 11, 1799, in Griffith J. McRee, 2 The Life and Correspondence of James Iredell 565 (D. Appleton 1858).

${ }^{120}$ Holmes, National Fast at 22 (cited in note 110).

${ }^{130}$ The modern ideal is that the "citizens" are "active, participant and rational." Peter B. Natchez, Images of Voting/Visions of Democracy: Voting Behavior and Democratic Theory 68 (Basic Books 1985).

${ }^{131}$ Packard, Federal Republicanism at 18 (cited in note 37).

${ }^{132}$ Governor Trumbell, The Good Old Fire (Farewell Address delivered 1783), reprinted
} 
Interestingly, the Federalists frequently contrasted the behavior of their hypothetical "good" citizen with that of the democratic "clubbist"; it is the democrat who most closely approximates the modern ideal citizen. Making this comparison, one Federalist said:

An honest Democrat is modest in his conduct; . . . he has a confidence in those delegated by the people to administer the government; he is ... no preacher of sedition, nor brawling disturber of the peace of society. But how opposite to this is the conduct and character of our modern democrats, our street declaimers. . . . These are devoted to excite jealousies and uneasiness among the people. ... [T]hey spend their whole time in traducing the rulers of the people, decrying the measures of government, and exciting commotions. ${ }^{133}$

The passivity of the Federalist citizen seems foreign to modern eyes, while the turbulent contentiousness of the democrat comes close to the actively involved citizen of the modern civics textbook. $^{134}$

\section{Federalist Claims to Democratic Superiority}

The Federalist theory of democracy has more to say for itself and a greater contemporary relevance than has been realized. The Federalists were acutely aware of a fundamental problem in democratic theory and pointed to distortions inherent in the modern system of public deliberation. If deliberation is the "conversation of the whole," how democratic it is depends on how equal access to the conversation is. A system that is in theory open to all but in practice permits only a few to participate travesties rather than fulfills

\footnotetext{
in Columbian Centinel 2 (July 25, 1798).

${ }^{123}$ Communications, Columbian Centinel 2 (Oct 1, 1794).

${ }^{134}$ Many other instances, of course, could be cited in which the Federalists criticized their opponents for doing what today we think citizens are supposed to do, that is, criticizing and opposing, through legal means of course, measures they do not like. See, for example, Communications, Columbian Centinel 3 (Sept 13, 1794) (criticizing the Jacobins for, among other things, "harangu[ing] the people at the corners of the streets, and in the market place; ... aspers[ing] the government of the Union, arraign[ing] those that administer it, insult[ing] the laws, and encourag[ing] opposition to them"); Communications, Columbian Centinel 2 (Oct 1, 1794) (criticizing "our modern brawling self-named democratic professors, our $\mathrm{Ge}$ netine leaders," claiming that "[ $t$ ]heir first principle and main object is, to oppose the lawsto attack the constituted authorities-to excite insurrections; and instead of venerating, they asperse and calumniate those sent by the people, to make and execute the laws"); Hezekiah Packard, The Plea of Patriotism: A Sermon preached in Chelmsford, on the day of Thanksgiving, February 19, 179518 (William Greenough 1795) ("Such combinations of men in a republican government, and in a season of peace, are I conceive very pernicious. By setting themselves up as a check upon government, they disturb and agitate the public mind.").
} 
democratic promise. The Federalists argued that discussing issues through the medium of the mass media and private political organizations such as parties introduced enormous inequalities of access, inequalities that could be avoided by deliberating through the representative process. In short, they argued that the modern open system of politics is in fact less egalitarian than the closed system of Federalism. Federalist criticism here is revealing because it corresponds to a point that democratic theorists have been making for most of this century. Federalists pointed out then, as theorists do today, that in modern democracy it is those who are politically organized and those who possess better access to the means of communication that dominate political discussion and hence political events. ${ }^{135}$ The Federalists focused on this inequality, stressing how most citizens were unable or unwilling to so participate. The central question Federalist arguments point to, then, is given the fact that only small minorities will participate in public discussion, is it better that the minority be a democratically responsible one, or one composed of those self-selected individuals who are best situated to participate in an open system? Viewed from this perspective the Federalist assertion that the legislature was and the clubs were not the "people" has real substance.

Though the modern tendency is to interpret radical activity as an early example of the "people's" involvement in politics, the Federalists correctly pointed out the small numbers actually participating this way. Bemoaning their influence, Congressman Ames pointed out, " $\mathrm{A}$ few hundred persons only are members of clubs." 136 Since representatives are few in number too, of course, it was not their numbers per se that were the problem. In this connection one of the most telling arguments the Federalists made is that in their system the minority engaged in public deliberation was democratically accountable to the populace at large. Implicitly comparing the clubs to democratically accountable officials, one Federalist denounced their power, saying "they are responsible to nobody for the exercise of it, and are to continue in office as long as they shall please." ${ }^{p 137}$ Washington, in calling the clubs "self created," emphasized their unaccountability and compared them to representatives who being "chosen for the express purpose" of discussing and determining political ques-

\footnotetext{
${ }^{135}$ Political scientists today are concerned about the gross inequalities that exist in terms of active participation and influence in a system to which everyone is connected, albeit as "passive consumers." See Quentin Skinner, Empirical Theorists of Democracy and their Critics, 1 Political Theory 287 (1973).

${ }^{136}$ Representative Ames, IV Annals of Cong 923 (Nov 26, 1794).

${ }^{137}$ Representative Dexter, IV Annals of Cong 938 (Nov 27, 1794).
} 
tions were responsible for what they said. ${ }^{138}$ The issue of their unaccountability is also implicit in the constant refrain that their influence is "arbitrary" and "tyrannical."

In asserting that the clubs were undemocratic the Federalists clearly specified the problem in democratic theory, still with us today, that they raised. A journalist pointed out that direct deliberations will greatly favor the organized:

It is easy to see ... that if part only of the citizens are formed into Clubs, and the others remain unassociated, the Clubs though a minority would have an over-ruling influence-and that excess of influence would be unfair, and utterly repugnant to the nature of an equal republican government. ${ }^{139}$

This argument, of course, suggests the possibility that if every citizen could be "associated" a system of direct deliberations might be just. Federalists, in fact, often speculated on just this question. They usually tentatively conceded the point in theory but raised doubts about both the practical possibility of a system of universal popular organization as well as about the equality of participation were such a system possible.

Congressman Ames, for example, took up the first issue. In asking if the clubs could serve the people "as a substitute" for their representatives, he pointed to their small number and asked rhetorically "to avoid this difficulty, shall the whole people be classified into clubs? Shall every six miles square be formed into a club sovereignty?" 140 Ames dismissed this possibility as ridiculous. A journalist, after similarly dismissing the practical possibility of universal participation, pointed out that to be just, not only would all have to be organized, but participation would have to be equal. He speculated: "Perhaps if a society of men were divided into bodies called Clubs, and those so regulated as to act equally and fairly, [the clubs might be acceptable]."141 He raised the question of what is to ensure that the clubs would "act equally and fairly"?

At the time the Federalists were writing, the most obvious obstacle to direct deliberation was the undeveloped state of communications. In the eighteenth century it was only in the cities, not the isolated countryside where the vast majority lived, that

\footnotetext{
${ }^{136}$ George Washington, Letter To Burgess Ball (Sept 25, 1794), in W.B. Allen, ed, George Washington: A Collection 596, 597 (LibertyClassics 1988).

${ }^{139}$ Deodatus-No. II, Columbian Centinel 1 (Sept 27, 1794).

${ }^{160}$ Representative Ames, IV Annals of Cong 923 (Nov 26, 1794).

${ }^{141}$ Deodatus-No. II, Columbian Centinel 1 (Sept 27, 1794).
} 
there existed the access to political information and capacity to organize with others that made public intervention in the deliberative process possible. The Federalists repeatedly stated that a system of direct popular politics would effectively disenfranchise the countryside, allowing city dwellers to disproportionately influence political events. In doing this they were only repeating arguments that had come up in similar contexts earlier in the century. ${ }^{142}$ Contrasting the requirements of universal organization and equal participation with the practical realities of eighteenth century politics, the above quoted Federalist tellingly asks, "Are the country people the better secured in their privileges, when they find their votes are guided or rendered null and void by the dark cabals in the cities?"143

The Federalist point about the geographical inequalities inherent in direct participation was made by contrasting the exclusive nature of the clubs with the inclusive nature of participation through the representative system. While public discussion by clubs included but a scattering of individuals in a few major cities, public discussion by representation included all citizens because the representatives came to the legislature "from the different parts of the Union," and brought with them "the sense of their Constituents." ${ }^{\prime 144}$ A similar point was made by Representative Murray. In a debate that repeatedly emphasized how few people were members of clubs, how geographically concentrated they were, and consequently how disconnected they were from the vast majority of Americans, Murray pointed out the very large number of representatives there were operating on all levels of government, how geographically dispersed they were, and how consequently every area in the country had a fair and equal ability to influence government. He listed a great number of elective offices and said they "all act in the States, counties, townships, and hundreds, in separate but relative circles, so as to preclude a partial attention to any one scene, to the exclusion of another."145

Though geography played an important role in Federalist criticisms, one would be mistaken to think they viewed the problem of unequal participation exclusively in these terms. The

\footnotetext{
${ }^{142}$ See, for example, K, Remarks on the Constitution of Pennsylvania, Pennsylvania Packet and Daily Advertiser 4 (Oct 15, 1776); To the Printers of the Pennsylvania Journal, The Pennsylvania Journal (Mar 12, 1777); To the Printers of the Pennsylvania Journal, The Pennsylvania Journal (Mar 26, 1777). Attempts to open the political system to greater public participation were criticized because only some of the people, those in the towns, could participate.

${ }^{143}$ Deodatus-No. II, Columbian Centinel 1-2 (Sept 27, 1794).

${ }^{14}$ Washington, Letter To Burgess Ball at 597 (cited in note 138).

${ }^{145}$ Representative Murray, IV Annals of Cong 907 (Nov 25, 1794).
} 
revolution in communications and transportation that would occur over the next fifty years would, after all, drastically reduce the isolation of the countryside, but it would not eradicate the deeper problems Federalist criticism pointed to. There are two features in the modern system of direct popular organization that the Federalists correctly pointed out are discriminatory. First, popular organizations are private, and participation in them therefore cannot be regulated in the same manner as participation in the institutions of state can, and second, popular organization is organization by opinion. Political organizations are open to those who agree with them, which will of necessity leave many out of the process. As the Federalists pointed out, both these characteristics contrast sharply with the traditional forms of popular participation the Federalists accepted. Whereas a Federalist would no more go to a meeting of one of these societies than a Democrat today would attend a Republican fundraiser, the customary town meeting had been open to every member of the town, and this access was legally regulated. One Federalist, complaining that most citizens were "excluded" from these clubs, not only mentioned their private character, but raised the issue of exclusion based on opinion. He stated, "If the common good be the object of these societies, then every one, who is interested in the common good, has a right to consult it with them,"146 but of course, only those sympathetic to the clubs' agenda attended. Another Federalist raising the same issues, but emphasizing the question of legal access, claimed that the clubs were not necessary since "[i]f the citizens think proper to meet and consult, what better club can be desired than a town meeting, where all is day light, and the law has regulated the proceedings in such a manner as to secure to every man his fair and equal privilege."147

It is by taking account of these real distortions of access that the full impact of the Federalist charge that the clubs were destroying democracy should be understood. The clubs were trying to replace an equitable system of representative deliberation with one that favored organized minorities like themselves.

In their attacks on the radicals the Federalists narrowed in on how, as the locus of political discussion moved from the legislature to the political organizations of the public realm, the will of a tiny minority of active radicals was displacing the will of the whole people. Revealingly using the word "delegated," Hamilton said, for example, that the problem with these "associations" is

\footnotetext{
${ }^{146}$ Order, Columbian Centinel 1 (Sept 3, 1794).

${ }^{147}$ Deodatus-No. II, Columbian Centinel 1 (Sept 27, 1794).
} 
that "they ... put in the stead of the delegated will of the whole nation the will of a party." ${ }^{\text {"148 }}$ Another Federalist, disagreeing with the democrat's very modern belief that the clubs "increase the popular influence upon" government, explained that as the clubs "augment the power of party over the laws and legislators, they diminish and obstruct that of the whole people. . . . The Government becomes their tool, and instead of being the people's it is the club's."149 Reflecting the same assumptions and afraid of the clubs' influence reaching to the House of Representatives, one congressman warned that unless stopped, "The power of the clubs will prevail even here and that of the people will proportionally decline." 150

Interestingly, the way Federalists usually condemned the undemocratic nature of radical influence was by turning the language of the democrats back on them and calling them "aristocrats." In terms of democratic theory, the Federalists clearly had a point. As one Federalist explained: "The clubs affect to be popular societies. They are not so. They are aristocratic. For what is their power and influence but usurped and exercised in derogation and sometimes in total destruction of the equal rights of others." 151

Another, referring to the displacement of the people's will by that of the clubs, added that the clubs were "an aristocratic junto, who wish to controul the constituted authorities and set up their will as the supreme law."152

\section{The Democratic Processes through which Deliberation Occurs}

The Federalist claim that deliberating through representatives is more democratic because the whole people are represented but only some participate in political organizations is, of

\footnotetext{
${ }^{148}$ Hamilton, Letter to George Washington at 439 (cited in note 85).

${ }^{149}$ Deodatus-No. II, Columbian Centinel 2 (Sept 27, 1794).

${ }^{150}$ Representative Ames, IV Annals of Cong 925 (Nov 26, 1794).

${ }^{151}$ Deodatus-No. II, Columbian Centinel 1 (Sept 27, 1794). See also Osgood, Thanksgiving Sermon at 26-27 (cited in note 53) (condemning the clubs for having "more than an equal voice" in the running of government and for being an "aristocracy").

${ }^{152}$ Communication, Columbian Centinel 3 (Aug 27, 1794). Federalist use of the term "aristocratic" was ubiquitous and was always used to denounce the disproportionate role Federalists alleged the democrats played in the representative process. One paper said, for example, that the Jacobin club leaders "are not Democrats, but Aristocrats both in principle and pursuit." Communications, Columbian Centinel 2 (Oct 1, 1794). See also Tammany Society, To the People of the United States at 206 (cited in note 74) (writing that clubs "violate[] this leading principle of republicanism, that rights are to be equally exercised. [They] discover [ ] under the garb of democracy the cloven foot of aristocracy").
} 
course, incomplete in itself. It is because modern commentators have not understood the relationship between Federalist attitudes and Federalist institutions that they have dismissed the former as undemocratic. ${ }^{153}$ The Federalist assertion that representatives deliberate for the people can only make sense in the context of the processes that made these deliberations "representative." Just as election, free speech, and party competition render modern laws democratic despite the fact that the people do not actually pass them, the Federalists specified the particular institutional processes that rendered legislative deliberations democratic. Just as the modern system is simultaneously democratic and repressive, in that it is designed to enable elected officials to implement popular preferences while denying the people the right to pass their own laws, the Federalist system facilitated "representative" discussions while denying the people the right directly to participate in them.

To enable the legislature to conduct "the dialogue of the whole" for the people, while denying the people the capacity to do the same, the Federalists postulated two vertical channels of communication: the utilization of representatives as information reporters and the use of petitions.

\section{Information gathering and reporting.}

The Federalists viewed the representative as a conduit, channeling information from his constituency to the national legislature. The fact that representatives played this role is rarely commented on in the literature but it is essential to understanding how representative systems functioned before the modern era. Since in the modern system the people deliberate directly, there is no corresponding need that representatives report local information to their colleagues, and consequently gathering of information is rarely mentioned as an important role of a modern legislator. In the Federalist system, however, representatives had to provide this service if deliberations were to take place at all. For this reason, instead of mentioning how government responds to parties and pressure groups, Federalist literature re-

\footnotetext{
${ }^{153}$ It is this elitism as well as the repression that forms the basis of the traditional view that the Federalists were "quasi" or even "anti-democrats" who adhered to an "undemocratic" or "insufficiently democratic" philosophy and lived in a "pre-democratic era." See Martin Diamond, Democracy and the Federalist: A Reconsideration of the Framers' Intent, $53 \mathrm{Am}$ Pol Sci Rev 52, 56 (1959) (discussing traditional interpretations); Russell L. Hanson, "Commons" and "Commonwealth" at the American Founding: Democratic Republicanism as the New American Hybrid, in Terence Ball and J.G.A. Pocock, eds, Conceptual Change and the Constitution 165 (Kansas 1988).
} 
peatedly emphasized the role of the representative as communicator of local knowledge. ${ }^{154}$ Deliberations could take place in the legislature because representatives possessed "a knowledge of the interests and feelings of the people," and could gather this knowledge in one place. ${ }^{155}$ As Noah Webster, a leading Federalist of the period, said, "The object of assembling representatives from all parts of a state is to collect a knowledge of all the interests of the whole community." 156 In an address that never mentions the public's organizing to press its demands on government, Federalist William Beers said legislators in order to "represent . . . society ... should have the most complete knowledge of the wants, the interests, and the character of their constituents" so they might "introduce [this information] into the ordinary deliberations" of the state. ${ }^{157}$ One finds these same ideas in The Federalist. Here there is no mention of Congress learning about the state of the nation through the media, or from organized lobbies or mass political parties. Instead, James Madison spoke of representatives as "vehicles" transporting information to the Congress. ${ }^{158} \mathrm{He}$ stated that local "knowledge . . . will be brought by the representatives of every part of the empire" to Congress. ${ }^{159}$ Hamilton's thought reflected the same assumptions. He asked, "If any question is depending in a State legislature respecting one of the counties, which demands a knowledge of local details, how is it acquired? No doubt from the information of the members of the county." He went on to suggest that the same principle applied to Congress, where knowledge about each state will be gathered from members from that state. ${ }^{160}$ This made the legislature, in

\footnotetext{
${ }^{254}$ It should be mentioned that the absence of parties and the various other vehicles of popular participation in politics can be noted in the realities of Federalist politics as well as in their rhetoric. Politicians were only in contact with the public when they were back in their constituencies. See, for example, James Sterling Young, The Washington Community 1800-1828 (Columbia 1966) (discussing the isolation of early Washington, D.C.). 84).

${ }^{155}$ Federalist 35 (Hamilton), in Rossiter, ed, The Federalist Papers 211, 217 (cited in note

${ }^{156}$ Although Noah Webster made this statement much later, his ideas remained fairly constant throughout his life and he was considered an arch-Federalist in the 1790s. Noah Webster, Letter to Daniel Webster (1837), in Warfel, ed, Letters of Noah Webster 478, 495 (cited in note 56).

${ }^{157}$ William P. Beers, An Address to the Legislature and People of the State of Connecticut 6, 14, 30 (T\&S Green 1791).

${ }^{158}$ Federalist 56 (Madison), in Rossiter, ed, The Federalist Papers 346, 347 (cited in note 84).

${ }^{159}$ Federalist 53 (Madison), in Rossiter, ed, The Federalist Papers 330, 333 (cited in note 84).

${ }^{100}$ Federalist 36 (Hamilton), in Rossiter, ed, The Federalist Papers 217, 218 (cited in note 84). David F. Epstein also mentions that the Founders envisioned representatives as information gatherers, reporting the particular needs and interests of their constituents to other
} 
the Federalist view, the only real repository of politically relevant information. Madison, emphasizing a legislature's unique position in terms of political knowledge, referred to "state legislatures [as the places] where all the local information and interests of the State are assembled." ${ }^{\text {"61 }}$ Consistent with this idea, representatives frequently returned to their constituents before important votes were made to take the "sense" of the people, suggesting that there was no other way of ascertaining local opinion. ${ }^{162}$

Communicating information, of course, is a two-way process, and the representatives served as vertical conduits in this sense too. The representative was considered a prime source of political information for his constituents and was expected to explain public actions to them either personally or through such practices as circular letters. ${ }^{163}$

2. Petitions: The Federalist alternative to political speech.

As was mentioned, there was, of course, another route by which knowledge about the people was transferred to the government. Petitions originated in the people themselves, not their representatives; they were an important political practice in the eighteenth century, even though recourse to them was only occa-

representatives. David F. Epstein, The Political Theory of The Federalist 155 (Chicago 1984).

${ }^{161}$ Federalist 56 (Madison) at 348 (cited in note 158). See also James Otis, The rights of the British Colonies Asserted and Proved, in Philip B. Kurland and Ralph Lerner, eds, 1 The Founders' Constitution 390 (Chicago 1987) (describing how representatives were themselves sometimes the primary source of legislative information in the British system).

${ }^{102}$ This had been the English and colonial practice. See Bernard Bailyn, The Origins of American Politics 84 (Vintage 1968); Edmund S. Morgan, Inventing the People: The Rise of Popular Sovereignty in England and America 215-17 (Norton 1988); John Phillip Reid, The Concept of Representation in the Age of the American Revolution 85-95 (Chicago 1989). In 1734, for example, Lord N. Somerset said Members of Parliament had often refused to take some action "until they had consulted their constituents." Philip Arnold Gibbons, Ideas of Political Representation in Parliament, 1660-1832 25 (Oxford 1914). This can also be found in Cato's Letters. "This is particularly the spirit of our constitution, in which the whole nation is represented; and our records afford instances, where the House of Commons have declined entering upon a question of importance, till they had gone into the country, and consulted their principals, the people." John Trenchard and Thomas Gordon, The Right and Capacity of the People to judge of Government, in Ronald Hamowy, ed, 1 Cato's Letters, or Essays on Liberty, Civil and Religious, and Other Important Subjects 266, 271 (Liberty Fund 1995).

${ }^{10}$ That personally explaining political events to constituents was a legislator's responsibility is implicit in the comment that the representatives were now "returning home to their different districts, to give you a narrative of our transactions, together with the motives and principles upon which we proceeded." See A Proposed Address from the Representatives ... to their Constituents, in The Pennsylvania Packet and Daily Advertiser 2 (Dec 27, 1784). For circular letters see Cunningham, ed, Circular Letters of Congressmen to Their Constituents (cited in note 7). 
sional. ${ }^{164}$ Although they were also drafted by individuals or small groups, petitions often claimed to speak for whole communities and originated in grand juries or town- or county-wide public meetings. Petitions were addressed to a branch of the legislature or the executive and were commonly transmitted by the people's local representative.

Petition writing is an excellent example of how the structures of representation shape popular involvement in politics. Delegating a process, after all, does not mean that the principal is uninterested or uninvolved with the process in question. It just means that her involvement is structured and channeled in such a way that her will is expressed not directly, but through the will of her agent. In structure, style, and tone, petition writing reflected this pattern of indirect expression.

Petitions were vertical in nature in that they originated in a specific locality, claimed to speak for only that locality, and were addressed and sent to those in government. A petition, for example, might be sent from "The Inhabitants of the Borough of Harrisburg" to the legislature of Pennsylvania. Because they were not communicated to the people as a whole, they were not like modern "horizontal" attempts to aggregate popular support behind a given position and force the government to comply. Instead, they were intended simply to inform elected officials about the conditions and sentiments of a local region, allowing the representatives to put this information together with knowledge of the sentiments and conditions of other localities and deliberate for the whole.

Consistent with the vertical nature of petitions, Federalists thought that petitions were best when they dealt with local concerns and grievances rather than national issues. The assumption was that the people of a locality could contribute to the deliberative process regarding local subjects because they could give elected officials information the officials might not otherwise have. Also, the practice of speaking authoritatively about local issues in no way infringed on the legislature's right to deliberate for the whole. Forthright statements on national concerns, however, would infringe on the right of elected officials to decide and speak for the people. ${ }^{165}$

\footnotetext{
${ }^{36}$ See Ruth Bogin, Petitioning and the New Moral Economy of Post-Revolutionary America, $45 \mathrm{Wm}$ \& Mary Q 391, 392 n 4 (1988) ("In accordance with earlier English practices, petitions were the principal channel of communication from inhabitants to the government.").

${ }^{165}$ Due to these attitudes, in Britain during this time petitions were primarily private in nature and few dealt with "state affairs." The concern was petitions should not infringe on
} 
Additionally, the deferential tone and language that these documents adopt reflects the fact that the authors viewed the deliberative process as delegated to their representatives. ${ }^{166}$ Deference is a way of keeping the "represented" and "representative" from exercising the same powers in what is to some extent a shared medium. The two entities can be separated more neatly in other processes. The sergeant-at-arms simply will not allow ordinary citizens to take seats and vote inside the chamber of an assembly. Deliberations, however, take place in the medium of public communications-a medium that cannot easily be reserved for a single entity. A deferential attitude provides part of the solution. By making it clear that their opinions are not of the same value as the representatives', and that they are not giving orders, the people can communicate with their elected officials without intruding on the latter's exclusive right to debate and decide issues. ${ }^{167}$

The most obvious manifestation of deference was the authors' use of words such as "honorable" or "esteemed" to address the representatives, or "humbly" in reference to themselves. ${ }^{168}$ In addition, petitions were phrased as requests and not as demands.

the prerogatives of Parliament. See Peter Fraser, Public Petitioning and Parliament before 1832, 46 History 195 (1961).

${ }^{166}$ This is not to suggest that deferential language does not also reflect social considerations. It is only to point out that it also contains a dimension that can only be understood in terms of democratic theory. See the discussion of the criteria by which the Federalists judged elected representatives in the text accompanying notes 206-12.

${ }^{167}$ Most of the attitudes here identified as specifically Federalist actually had much wider currency. Sometimes these ideas were also shared by anti-Federalists or Jeffersonians (although rarely to the same extent), and virtually all of them have colonial precedents. This is certainly the case regarding deference. See, for example, John B. Kirby, Early American Politics-The Search for Ideology: An Historiographical Analysis and Critique of the Concept of "Deference", $32 \mathrm{~J}$ Pol 808, 820-22 (1970) (discussing the deferential attitudes of the eighteenth century). See also Richard R. Beeman, Deference, Republicanism, and the Emergence of Popular Politics in Eighteenth-Century America, 49 Wm \& Mary Q 401 (1992); Jay B. Gilsdorf and Robert R. Gilsdorf, Elites and Electorates: Some Plain Truths for Historians of Colonial America, in David D. Hall, John M. Murrin, and Thad W. Tate, eds, Saints and Revolutionaries: Essays on Early American History 207-44 (Norton 1984); J.R. Pole, Political Representation in England and the Origins of the American Republic (California 1966); Stephen B. Presser, The Original Misunderstanding: The English, The Americans, and the Dialectic of Federalist Constitutional Jurisprudence, $84 \mathrm{Nw}$ U L Rev 106, 109 (1989) (pointing out that "aristocracy and the need for deference" was more important in the early republic than is commonly recognized).

${ }^{183}$ See Pittsfield Petitions, May 29, 1776, in Oscar and Mary Handlin, eds, Popular Sources of Political Authority: Documents on the Massachusetts Constitution of 178088 (Belknap 1966); Pittsfield Memorial, December 26, 1775, in id at 61. One historian speaking of petitions commented that '[t]he word humble' was ubiquitous in both [17th and 18th] centuries," and that "[p]etitionary language by its very nature reduced the petitioner to subservience." Richard L. Bushman, King and People in Provincial Massachusetts 47-48 (UNC 1985). Language had become more modest by the 1790s. 
This wording respected the fact that only elected officials were believed to have the right to make political decisions. Additionally, in order to ensure that they were not misinterpreted as public intrusions into the deliberative process, these documents commonly included prefaces apologizing for commenting on public issues and reassuring those receiving the communication that their judgments would be respected and that there was no intent to dictate to them. For example, a 1798 address to the president declared: "We come not, however, to dictate or interfere in the affairs of the nation. We are content that the powers of government are exercised by those with whom they are constitutionally lodged." ${ }^{169}$ The same language can be observed in an address to President Adams that declared that "a sense of propriety . . . dictate[d]" that in normal circumstance "we should not presume to obtrude our sentiments on any branch of the constituted authorities of the country."170

The deferential tone of these addresses, and constituent/representative contacts generally, should not deceive the reader into thinking that these communications were inconsequential. In order to deliberate for the people, elected officials had to have information about them. Petitions provided this information and therefore had a privileged status. ${ }^{171}$ Traditionally, greater leeway was granted to what was said in a petition than to what was put into print; some even argued that anything in a pe-

\footnotetext{
${ }^{169}$ Celebration of Independence, Albany Centinel 2 (July 17, 1798).

${ }^{270}$ Under the heading Federalism of the East, this petition was addressed, "To the President of the United States," Columbian Centinel 1 (Oct 13, 1798).

The language used in Federalist petitions would amaze anyone who believes that this group of Americans understood representative government as functioning even remotely as it operates now. Repeatedly, petition writers assured those in office that they did not wish to infringe on their decisionmaking authority. See, for example, The Address of the Inhabitants of the borough of Harrisburg, in the State of Pennsylvania: To the President of the United States, Albany Centinel 2 (May 25, 1798) (stating that, although the authors were "disinclin[ed] to intrude upon the managers of the public concerns," "there may be a propriety in the declaration of sentiments which, in more settled times, might at least be thought superfluous"); Address of the Inhabitants of the Town of Haverhill, Commonwealth of Massachusetts, To the President of the United States, Columbian Centinel 2 (June 2, 1798) (stating that "while we disapprove an interference of the people with the administration of our national government, [due to the crisis with France] we consider it our duty" to declare support for the government); Noble Address of the Militia Officers of New-Jersey: To the President of the United States, Albany Centinel 1 (May 25, 1798) ('We come not, Sir, to dictate-[policy matters] are questions entrusted to those in whose patriotism we confide, and according to their decision we shall always be prepared to act.").

${ }^{171}$ When legislative sessions had been closed to the public earlier in the century, legislators could report things to their constituents, such as the votes and debates of the assembly, that could not at the time be reported in newspapers. See J.R. Pole, The Gift of Government $v, 98,104$ (Georgia 1983) (describing the gradual opening of assemblies to the public).
} 
tition enjoyed complete immunity from libel. ${ }^{172}$ Additionally, powerful norms obliged the legislature to read and respond to each petition. ${ }^{173}$

The reverse side of the privileged role of petitions is that popular expression had to be restricted to that format, and the petitions themselves had to be used in their proper "vertical" way. The purpose of petitions was to channel information from localities to elected officials, so that the officials could aggregate, formulate, and articulate public opinion. For this reason, using petitions to communicate with other localities was considered a grave misuse: their use in this "horizontal" sense involved the people directly in the deliberative process. ${ }^{174}$ Charles Lee, for example,

\footnotetext{
${ }^{172}$ In the pre-modern tradition in which the Federalists operated, more importance was placed on protecting the rights of petitioners than on protecting the rights of those wishing to communicate by means of the press. Testimony surrounding the Trial of the Seven Bishops for Publishing a Libel (1688), provides a good example. See Kurland and Lerner, 5 The Founders' Constitution at 191 (cited in note 161). A prosecutor compared the Bishops' supposedly libelous petition to similar language in a book. The Bishops' counsel immediately responded, "Don't compare the writing of a book to the making of a petition; for it is the birthright of the subject to petition." Id. Because petitions were more important than other printed material as a form of political communication, they merited special protection. See also Larry D. Eldridge, A Distant Heritage: The Growth of Free Speech in Early America 1519 (NYU 1994) (pointing out that in seventeenth century America individuals could complain about or deride their government and its officials more freely through official channels, such as petitions or appeals from court judgments, than they could through unofficial channels, such as the press); Kurland, 55 Miss L J at 255 (cited in note 3), quoting James Burgh, Political Disquisitions: Or, An Enquiry into Public Errors, Defects and Abuses, bk I, ch IX at 247 (1775) ("In a petition to parliament, . . . libellous words are not punishable; because freedom of speech and writing are indispensably necessary to the carrying on of business."); Norman B. Smith, Shall Make No Law Abridging . . . An Analysis of the Neglected, but Nearly Absolute, Right of Petition, 54 U Cin L Rev 1153, 1153 (1986) ("The Supreme Courts recent decision ... reflects an inadequate understanding of the history and purpose of [this] right ... and placed inappropriate limitations on [it].").

${ }^{173}$ The importance and status of petitions can be measured by the fact that legislative agendas were in large measure set by petition writers. See Steven A. Higginson, $A$ Short History of the Right to Petition Government for the Redress of Grievances, 96 Yale L J 142, 142-47 (1986). About half of all eighteenth century legislation was in response to petitions. See Alan Tully, Constituent-Representative Relationships in Early America: The Case of PreRevolutionary Pennsylvania, 11 Can J Hist 139, 145 (1976) (citing the percentage of Pennsylvania laws passed in response to petitions from 1717-75). See generally Raymond C. Bailey, Popular Influence upon Public Policy: Petitioning in Eighteenth-Century Virginia (Greenwood 1979) (examining the role of petitions).

${ }^{174}$ In England, for example, attempts to organize petition campaigns in which different localities sent Parliament similar petitions at the same time were considered illegal by many. These campaigns were objectionable because, by organizing and aggregating public opinion behind a particular program, they were, in effect, making the public itself the deliberating forum and forcing the hand of Parliament. See Fraser, 46 History at 202 (cited in note 165). Also, it was illegal to submit a petition to Parliament or the King with more than ten signatures, or for petitions to be delivered by more than ten people, to avoid popular pressure on government and to preserve the delegated nature of political decisionmaking. See Bushman, King and People at 46-50 (cited in note 168). Additionally, Fraser mentions that groups meeting to discuss politics but not sending a petition to Parliament were some-
} 
criticized a petition written by the people of Albermarle County, Virginia, because, he claimed, despite the fact that it was "formally addressed" to Congress, its real intended audience was "the people at large. ${ }^{\text {p175 }}$ Assuming that the legislature is the only appropriate decisionmaking forum, Lee makes the highly unmodern assumption that anyone wishing a genuine "repeal or reform of the law" would want to communicate exclusively with Congress. Revealing the way the formation of popular opinion appears to those who do not believe this is what the people should be doing, he added that such activities could only be the reflection of a malevolent and purposeless desire to "create discontents among the people at large. $\$ 176$

Even more forbidden than misusing petitions was to step outside them altogether. When condemning the radicals for opposing or obstructing the government, the Federalists commonly argued that the people had no need to behave like this since they had perfectly legitimate ways, such as petitioning, to change the direction of government. George Washington, for example, condemned the clubs for their "permanent" political organization and their "arrogant presumption" to publicly denounce an act of Congress. ${ }^{177}$ In the very same letter, however, he added the caveat that, of course, "no one denies the right of the people to meet occasionally, to petition for, or remonstrate against, any Act of the Legislature. ${ }^{1178}$ What bothered Washington was not public discontent but the manner of its aggregation and expression.

A similar point was made by Reverend John Smalley. He said that since the representative system itself provided channels for the expression of popular discontent, there was no excuse for private political organizations championing popular causes: "It may next be observed; that in republican governments, there is the least occasion for illegal associations, or popular tumults, to obtain a redress of grievances. If there be any maladministration, or any fault in the constitution, a remedy is pro-

times prosecuted. If a meeting's purpose was not the vertical communication implicit in the petition, it was presumably to horizontally communicate and agitate amongst the people themselves and this was not acceptable. See Fraser, 46 History at 203.

${ }^{175}$ Lee, Defence of the Alien and Sedition Laws at 14-15 (cited in note 95). British Parliamentarians were similarly offended when they received petitions whose real purpose was to communicate with and agitate the people themselves. See Fraser, 46 History at 207 n 55 (cited in note 165).

${ }^{178}$ Lee, Defence of the Alien and Sedition Laws at 14 (cited in note 95).

${ }^{17}$ Washington, Letter To Burgess Ball at 597 (cited in note 138) (emphasis removed). See also Marshall Smelser, George Washington and the Alien and Sedition Acts, 59 Am Hist Rev 322, 324 (1954).

${ }^{178}$ Washington, Letter to Burgess Ball at 597 (cited in note 138). 
vided, without disturbing the public peace."179 Like a good Federalist, he believed that while respectfully worded petitions were acceptable, political parties were not.

The same point was made by Timothy Pickering when he complained of a petition from the freeholders of Prince Edward County. In this case, the people used the correct channel-a petition-but Pickering thought their language was too strong and questioned its propriety. He made the point that the people can express anything they want, provided they do so with language that respects the position of elected officials as public opinion formers and decisionmakers. Although condemning this particular petition, he agreed that the petitioners in principle had "the liberty ... of examining the proceedings of the President and Congress," and that this "claim, which while exercised with decency, and without insult to the constituted authorities, and without a design or tendency to excite discontents and disobedience to the laws of our country, will never be questioned."180 In other words, if the people respect the proper channels and forms, they are perfectly free to communicate with and influence government.

\section{The role of elections.}

Not only did channels exist that allowed the people to communicate discontent to their representatives, but the people also had the ability to remove their representatives from office. While agents must be supported while fulfilling their tasks, principals may still judge their performance periodically. Elections filled this role, though their purpose was conceived differently than in the modern system. The stricture of support and the structured nature of participation meant that the public was viewed as normally absent from the political arena. Nevertheless, despite their apparent comparative political insignificance between elections, power flowed to the people at these moments of judgment; the people felt free to exercise their power through dismissing their elected officials.

Both the nominal impotence and ultimate power of the people are inherent in the Federalist insistence that political muscle could be flexed only through elections. In the words of Noah Webster, although "the powers of the people [we]re principally re-

\footnotetext{
${ }^{179} \mathrm{John}$ Smalley, On the Evils of a Weak Government (May 8, 1800), in Sandoz, ed, Political Sermons 1417, 1435 (cited in note 53).

${ }^{180}$ From Timothy Pickering, to P. Johnson, Esquire, Albany Centinel 2 (Oct 16, 1798).
} 
stricted to the direct exercise of the rights of suffrage," ${ }^{\text {"181 }}$ that power "returned" to the people on election day. ${ }^{182}$ This point is also inherent in the comments found in the Federalist Columbian Centinel defending the old order against radicals advocating continuous popular political involvement: "[T]he sovereignty of the people is delegated to those whom they have freely appointed to administer [the] constitution, and by them alone can be rightfully exercised, save at the stated periods of election, when the sovereignty is again at the disposal of the whole people."183

The contrast between the public's general absence and election day power corresponds to the contrast between the stricture of support and the freedom to dismiss representatives. In the Federalist scheme, it is inconsistent to openly oppose an agent while he is performing the errand the people have asked him to do. This, however, does not mean that the public must retain confidence in him or wish to renew his tenure.

Since the obligation to support flowed from the act of election, the Federalists were obligated to support their officials as long as they. held office. As one Federalist explained, there is a clear dichotomy: "Ignorant, inefficient, and corrupt magistrates and legislators should be removed from office; but while they remain, they should be treated with respect."184 Another Federalist, criticizing the clubs' opposition to government, stated that "[i]f men dislike the present Officers of our Government, let them vote

\footnotetext{
${ }^{181}$ Webster, Letter to Joseph Priestley, III at 207 (cited in note 56). Historians have also noted this eighteenth-century attitude. See Buel, 21 Wm \& Mary Q at 189 (cited in note 22) ('[T]he constituents' legitimate powers were confined to the election of their particular representatives.").

${ }^{122}$ For example, a minister said that in governments like ours, . . . all delegated power may be said, by means of frequent elections, to return, after short intervals, to those who gave it." Mellen, Election Sermon at 21 (cited in note 72). The moments when constitutions were formed enjoyed an analogous status with election days. At both times the people possessed their full sovereignty because there was no government to delegate it to. For example, one Federalist wrote, "The people never act, in their sovereign capacity, but either in framing or dissolving a Constitution. While the constitution is in force, the people are either subjects or agents of the constitution." Alexander Addison, Analysis of the Report of the Committee of the Virginia Assembly (Philadelphia 1800), in Hyneman and Lutz, eds, 2 American Political Writings at 1058 (cited in note 82). This pattern of thought can also be found before the Federalists even existed. See, for example, Benjamin Rush, On the Defects of the Confederation, in Dagobert D. Runes, ed, The Selected Writings of Benjamin Rush 26, 28 (Philosophical Library 1947) (writing, in 1777, that the people "possess [their sovereignty] only on the days of their elections. After this, it is the property of their rulers"). For an English parallel, see H.T. Dickinson, ed, Politics and Literature in the Eighteenth Century 155 (Dent 1974), quoting James Burgh, I Political Disquisitions 28-29, 36-38, 51-54 (1774).

${ }^{103}$ Order, Columbian Centinel 1 (Sept 3, 1794).

" Freeman, A Sermon for December 15, 1796 at 16 (cited in note 103). See also A Friend of Order, Columbian Centinel 1 (Aug 4, 1798) (insisting that "virtuous men," even if they have "irresistible proof" that an official is misbehaving, "do not openly accuse him").
} 
for others at the next election." While magistrates hold their office, however, "all honest men will afford them support-exercising only the constitutional mode of changing men."185 That is to say, if unhappy with a representative, men are free to elect another through "constitutional modes," but cannot oppose, and must support, the man they dislike as long as he still holds office.

A deferential political system does not imply powerlessness, since the people choose to whom they defer. ${ }^{186}$ The combination of an obligation to support with a perfect freedom to defeat at the polls, although strange to modern eyes, runs throughout Federalist writings. Interestingly, communications exhorting the people to respect and defer to elected officials often at the same time emphasized the importance of the people's discretionary power of election. One Federalist, for example, argued that the people should rely on their legislature's "collected and united wisdom" rather than oppose government and engage in "popular clamour." ${ }^{187}$ Nevertheless, he also spoke of the important role the "freedom and frequency of election" played in the political system, implying the power of the people both to choose good men and to turn out bad ones. ${ }^{188}$

The Federalist combination of deference and removal power also has clear parallels in our modern system wherever we have delegated authority to our representatives. For example, because the power to pass laws is delegated, the principles of agency demand that the people must obey each law as the legitimate expression of their will even if they never supported or no longer support the legislation. To change the law, citizens must operate through their representatives, either persuading them to repeal the law or electing new delegates who will. The Federalist conception of delegated deliberation is identical. In it, citizens are required to respect the results of the representatives' deliberation as the legitimate expression of their own will. They may persuade

\footnotetext{
${ }^{185}$ Albany Centinel 1 (Oct 12, 1798). That the people have a right to change governments through election, but not to oppose government, has been noticed by historians. See, for example, Smith, Freedom's Fetters at 420 (cited in note 14).

${ }^{186}$ The tendency of modern writers to mistake deference for submission has been commented on by a number of scholars. See, for example, Beeman, $49 \mathrm{Wm} \&$ Mary Q at 401-30 (cited in note 167); Gilsdorf and Gilsdorf, Elites and Electorates at 207-44 (cited in note 167); Kirby, $32 \mathrm{~J}$ Pol at 820-22 (cited in note 167); Pole, Political Representation in England at 46 (cited in note 167).

${ }^{187}$ Trumbull, The Good Old Fire (Farewell Address delivered 1783), reprinted in Columbian Centinel 2 (July 25, 1798).

${ }^{188}$ Id. See also William Tudor (the elder, of Boston, 1750-1819), A Discourse Delivered at the Request of the Massachusetts Charitable Fire Society, June 1, 1798 10-11 (Samuel Etheridge 1798) (emphasizing the evils of "party spirit" as well as recognizing the importance of the people's electoral check on their leaders).
} 
their representatives to take a different course of action, or they may replace their representatives, but open opposition is impermissible, because it implies the resumption of powers they have delegated.

\section{E. A Federalist Theory of the First Amendment}

However well-developed the Federalists' theory of democracy, and however strong their opinions about the illegitimacy of clubs and disrespectful political speech, it would be a mistake to believe that these beliefs transferred directly into the constitutional sphere. The Federalists may have believed that behavior that infringed on authority delegated to the government was "unconstitutional" in the sense that it violated the basic norms, expectations, and structures inherent in the political system; however, this does not mean that they supported specific legal remedies in such cases. Specifically, Federalist opinion shifted depending on whether speech or assembly was at issue. Additionally, freedom of speech as it applies to the press-and virtually all the political "speech" at issue during the period was printed-deserves separate consideration. Their understanding of press liberty, though definitely consistent with their theory of representation, accommodates elements more central to modern than Federalist conceptions of democracy and thereby suggests historical transition.

Federalists asserted a belief in a general constitutional protection for the freedom of speech, but they hedged their statements with qualifications meant to protect elected officials in the proper operation of the authority delegated to them. In practice this meant that individuals were perfectly free to criticize government-provided they did it in a manner that did not challenge the right of the legislators to speak for "the people." One Federalist explained:

I am by no means adverse to open, fair, and candid discussions of political questions; but am however, far from wishing to encourage those societies whose $* * *$ professed design is the superintendance of that government $* * *$ [and] evident tendency, by obtaining an influence, is to lessen the power of the officers of government, and to lead, or rather drive, the legislature, where ever they please. ${ }^{189}$

Another Federalist, revealing the same attitude, said:

${ }^{289}$ To the Vigil, Gazette of the United States 2 (Dec 6, 1794). 
A decent manly statement of opinion, and the reasons on which it is founded, is the right and honor of the patriot and republican; and will never endanger the peace of society. But charges of wicked designs, . . . inflammatory publications and menacing declarations, misrepresentations and calumnies, are of base original and dangerous tendency; and may prove destructive to Tiberty and order. ${ }^{190}$

Reminding his readers that slander violated the norm of support, he added, "Let us place that confidence in those whom we choose for our rulers, which is necessary to their success in the administration of government."191

The Federalists' theory of libel is the exact inverse of the modern one. Modern First Amendment law reasons that the need for the people to deliberate means that less protection against libel can be offered public officials than can be extended to ordinary citizens. ${ }^{192}$ But in the Federalist conception, democratic obligations to respect government officials existed that did not apply to ordinary individuals. As the Sedition Act attests, most Federalists seemed to agree that these obligations could be legally enforced. Their feelings regarding whether the obligation to refrain from political organizing could be legally enforced, however, were more ambiguous.

${ }^{100}$ Kendal, Thanksgiving Sermon at 2, 29-30 (cited in note 30). Another Federalist precisely defined a seditious statement as one that refuses to recognize public officials as the legitimate expressors of the public will. See William White, A Sermon on the Duty of Civil Disobedience, as Required in Scripture, Delivered in Christ Church and St. Peter's, April 25, 1799, Being a Day of General Humiliation, Appointed by the President of the United States 20-21 (Philadelphia 1799). White elaborated:

Under ... a [representative] government, to deny the right of expressing private sentiment on the administration of its powers, would be contrary to the liberal spirit which it breathes. But when this freedom is abused to the rendering of rulers odious by misrepresentation and falsehoods; When recourse is had to the low artifices of faction, much more to the outrageous violence of sedition and of treason; Or, what is the root of all these evils, when there is an intemperate opposition, disdaining submission to public measures, however unequivocally supported by legitimate declarations of the general will [the instigators must be condemned].

Id. White identified the "general will," of course, with the legislature. See also Representative Dexter, IV Annals of Cong 936 (Nov 27, 1794) ("Let men meet for deliberating on public matters; let them freely express their opinions in conversation or in print, but let them do this with a decent respect for the will of the majority, and for the Government and rulers which the people have appointed.").

${ }^{192}$ Kendal, Thanksgiving Sermon at 30 (cited in note 30).

${ }^{192}$ Reasoning that the people's need for unfettered freedom of discussion outweighs concern for an official's privacy and reputation, the Supreme Court has ruled that "public men, are, as it were, public property." New York Times v Sullivan, 376 US 254, 268 (1963), citing Beauharnais v Illinois, 343 US 250, $263 \mathrm{n} 18$ (1952). Because the shift in understanding concerning representation occurred in the early nineteenth century, public men had less protection than ordinary individuals for the bulk of that century too. 
As with speech, the Federalists believed that individuals should be free to associate as they wished; but the Federalists required that this association not interfere with the need to agree with and support the deliberations of elected officials. Thus, while associations of a nonpolitical nature-or those interested in politics on a more philosophical level-were acceptable, only gatherings associated with the petition process could engage in overtly political activities. The Federalists did not confound freedom of assembly with freedom of association, unlike many modern theorists. ${ }^{193}$ When club members, for example, attempted to use the freedom of assembly principle to defend themselves, the Federalists argued that the right of assembly applied to public meetings, not private political clubs. Comparing the two, one Federalist said: "It is often said that all men have a right to meet and consult in a peaceable and orderly way. But [are clubs] the orderly way in our country, where better legal and known ways are in use."194

Another Federalist addressed not the disruptiveness of the clubs, but the way in which they of necessity excluded people from the political process. Asking, "Who are the People?" he answers by saying that they are "The Whole People." Therefore, he queries, "Does the declaration of rights say, that a part of the people have a right, even in an orderly and peaceable manner, to assemble and consult the common good of the whole." 195 Whereas traditional "town hall" meetings had been based on local geographical and political entities, and had been open to all members of those entities, the modern organizations were "exclusive" in that they were organized by and for only those of a particular political persuasion. Today we assume that these subgroups are protected in their right of association. This interpretation, however, is not what the Federalists had in mind, nor is it required by the text of the First Amendment. "The people" is an inclusive term, yet any political subgrouping is by definition exclusive. No one can argue that the National Rifle Association, for example, or any other political organization, can really be called "the people." Even a major political party cannot really make that claim. A meeting in which all members of a given locality are welcome, however, has a better claim, at least to represent "the people" of a given area.

\footnotetext{
${ }^{193}$ This had been the traditional understanding. See Zechariah Chafee, Jr., Right of Assembly, in 2 Encyclopedia of the Social Sciences 275 (MacMillan 1948).

${ }^{19}$ Deodatus-No. II, Columbian Centinel 1 (Sept 27, 1794).

${ }^{195}$ Order, Columbian Centinel 1 (Sept 3, 1794).
} 
Yet while the Federalists clearly opposed political clubs on a normative level, it does not follow that every Federalist therefore assumed that they were illegal. In fact, although the clubs were universally condemned as pernicious, there was a range of opinion concerning their constitutional and legal status. ${ }^{196} \mathrm{~A}$ few Federalists were convinced that the clubs were illegal and unconstitutional: "The democratical . . . societies . . . are evidently nurseries of sedition, and ... I believe in their institution are unlawful, as they are formed for the avowed purpose of a general influence and control upon the measures of government."197

Most, however, were more ambivalent. Typical was William Cobbett's response. Despite calling them "an act of rebellion," and believing that their very existence "impl[ied] a systematic opposition to the lawful rules of the land," he believed that the clubs were "unpunishable by law." 198 Similarly, another admitted "the strict right to meet in clubs," even though he argued that the clubs "abuse[d] . . . the right." ${ }^{\text {"199 }}$ As Representative Fitzsimons said, the clubs were "institutions, not strictly unlawful, yet not less fatal to good order and true liberty."200 Expressing a similar sentiment, Representative Dexter said that "such societies were in themselves, wrong;" but he was "still not for making laws against them."201

Perhaps the most revealing reflection of Federalist ambivalence was a 1795 declaration from Tammany Hall: "We claim it the unquestionable right of citizens, to associate . . . but such associations are only excellent as a revolutionary means, when government is to be overturned. An exercise of this right, in a free and happy country like this, resembles the sport of firebrands; it is phrenzy."202

The ambiguities of the Federalist position, however, concern historical transitions, not merely how directly norms translate into law. Some authors have argued that freedom of the press played a "structural" role in the Founders' understanding of the

\footnotetext{
${ }^{196}$ This is undoubtedly in part because the clubs were a relatively new phenomena, and the issues were therefore still unsettled.

${ }^{197}$ Oliver Wolcott, March 26, 1795, in George Gibbs, ed, 1 Memoirs of the Administrations of Washington and John Adams 178, 179 (William Van Norden 1846).

${ }^{193}$ William Cobbett (Peter Porcupine), History of the American Jacobins, Commonly Denominated Democrats 20 (Philadelphia 1796).

${ }^{199}$ Deodatus-No. II, Columbian Centinel 1 (Sept 27, 1794).

${ }^{200}$ Representative Fitzsimons, IV Annals of Cong 899 (Nov 24, 1794).

${ }^{201}$ Representative Dexter, IV Annals of Cong 910 (Nov 25, 1794).

${ }^{202}$ Though historically Tammany Hall has been associated with the Democratic Party, its early members clearly had pro-Federalist sympathies. See Tammany Society, To the People of the United States at 205 (cited in note 74).
} 
political process. That is to say, liberty of the press played an essential role in the political system. ${ }^{203}$ This would appear inconsistent with Federalist theory. The press by its very nature is "horizontal." It connects members of the public on a cross-constituency basis, and, by giving them political information, it allows them to "deliberate." This violates the "vertical" structure of Federalist communications (representatives and petitions). Though freedom of discussion is essential in the Federalist system, it is essential for the representatives; they are deciding, not the people. The existence of a notion of press liberty, therefore, could be cited as evidence of an increasingly modern conception of democracy, but this view is likely mistaken. The Federalists interpreted liberty of the press in a manner completely consistent with their understanding of the representative process, suggesting they were accommodating new institutions and pre-occupations to an old theory.

The role the Federalists assigned press liberty is quite different from that assigned the media in modern democracy. Modern defenses of the freedom of the press, for example, are characteristically framed in very broad terms, stating the people's need to know about and express themselves on the problems and policy options confronting the nation..$^{204}$ Eighteenth century rationales, in contrast, are framed in very narrow terms. ${ }^{205}$ They are concerned almost exclusively with either judging the competence of those elected to office or with uncovering their betrayal of the public trust. The shift in emphasis follows from the fact that the

${ }^{203}$ See, for example, David Anderson, Levy vs. Levy, 84 Mich L Rev 777, 777-86 (1986); Anderson, 30 UCLA L Rev 455 (cited in note 3). See also Chafee, Free Speech in the United States (cited in note 8).

${ }^{20}$ Modern free speech statements typically stress the fact that the people must decide questions of policy. See for example, Vincent Blasi, The Checking Value in First Amendment Theory, 1977 Am Bar Found Res J 521, 555 (1977) (paraphrasing Alexander Meiklejohn's view that " $[t]$ he agents of the electorate have no authority to decide what serves the general welfare; that determination ... can be made only by a continuing process of informed, disinterested reflection and discussion by the citizenry as a whole"); Schauer, Free Speech and the Argument from Democracy at 243-44 (cited in note 8) (arguing that "[i]f political deliberation is in fact central in our conception of freedom of speech, then the implication is that political considerations explain this special solicitude").

${ }^{206}$ Other scholars have noted that at this time freedom of the press was justified in very narrow terms that did not reflect the people's involvement in the governing process. See, for example, Blasi, 1977 Am Bar Found Res J at 542 (cited in note 204) (noting that unlike modern justifications, eighteenth century freedom of the press rationales held that "the role of the ordinary citizen is not so much to contribute on a continuing basis to the formation of public policy as to retain a veto power to be employed when the decisions of officials pass certain bounds" that qualify as a breach of the public trust). But see Thomas I. Emerson, The System of Freedom of Expression 5 (Random House 1970) (claiming that "the basic theory underlying the legal framework [of the freedom of the press] has remained substantially unchanged since its development in the seventeenth and eighteenth centuries"). 
people in the Federalist system do not deliberate themselves, but instead choose others to do so for them. They have less need to be exposed to all of the available alternatives; the fidelity and ability of the agent becomes the primary purpose for the freedom.

The literature of the era revealed the emphasis eighteenth century theory placed on examining the trustworthiness and competence of the representative. An influential pamphlet stated that freedom of the press was useful "to see whether [public affairs] be well or ill transacted."206 Striking a similar note, the Continental Congress in its "Address to the Inhabitants of Quebec" repeated the standard rationale of fear of abuse of authority by stating that freedom of the press is good because with it "oppressive officers are shamed or intimidated into more honourable and just modes of conducting affairs. ${ }^{207}$ Reiterating the point, a writer for the Independent Gazetteer spoke of how a free press could expose the "faults" of elected officials. ${ }^{208}$

None of these commentators, however, defended freedom of the press on the basis that the people need to know about and resolve the various problems and options confronting the nation. The commentators entirely concentrated on the behavior of the representative. In contrast, although modern justifications for the freedom of the press include questions of trust and competence, they are not restricted to these concerns.

It is important to note here that Federalist thought on press liberty is just an extension of their theory of elections. Since the Federalist citizenry were selecting an agent to make decisions for them, elections could not be perceived as facilitating popular choice between different ideological and programmatic options, since decisionmaking is precisely what had been delegated. Elections, then, were not about choosing between political alternatives but about selecting others to choose between the alternatives for them. For this reason elections were about finding candidates with the highest abilities and moral integrity. The former

\footnotetext{
${ }^{206}$ Trenchard and Gordon, Of Freedom of Speech, in Hamowy, ed, Cato's Letters 110, 111 (cited in note 162).

${ }^{207}$ Appeal to the Inhabitants of Quebec (Philadelphia 1774), in Hyneman and Lutz, eds, 1 American Political Writings 231, 234 (cited in note 82).

${ }^{203}$ Candid, Independent Gazetteer, or the Chronicle of Freedom (Dec 14, 1782), in Dwight L. Teeter, Jr., Decent Animadversions: Notes Toward a History of Free Press Theory, in Donovan H. Bond and W. Reynolds McLeod, eds, Newsletters to Newspapers: EighteenthCentury Journalism 237, 242 (W Va 1977). One might also see Article 35 of the Pennsylvania Constitution of 1776 in this regard. See also Samuel Eliot Morison, ed, Sources and Documents illustrating the American Revolution, 1764-1788, and the formation of the Federal Constitution 173 (Clarendon 1923). Article 35 has commonly been taken to be a good example of early freedom of the press ideology. It justifies freedom of the press, however, only in terms of the people's right to find out if elected officials are behaving or misbehaving.
} 
ensured that they had the capacity to perform their function, and the latter was necessary to guarantee that they used these superior endowments for the people's benefit.

While the modern tendency is to justify elections in terms of popular choice, what is striking about discussions of elections by Federalists is that policy preferences are not mentioned and are, implicitly or explicitly, rejected as the appropriate basis for electoral choice. ${ }^{209}$ Instead, things like character, ability, knowledge, and trustworthiness are normally held to be the only valid criteria upon which voting decisions should be made. In a work that never mentions the candidates' policy differences as a legitimate basis for voter discretion, James Iredell said the people "must choose able and disinterested men to make [laws]."210 Again ignoring the policy dimension, the Federalist Columbian Centinel referred to elected officials as "those who by their exemplary conduct and virtuous habits have obtained the administration of [government]."211 And Hamilton said of the electorate, "[T]heir votes will fall upon those in whom they have the most confidence."212

Liberty of the press, of course, facilitated electoral choice. The point here is that it was part of a larger theory of agency selection that did not imply direct popular involvement with policy choice. It was therefore, like the Federalists' thought on freedom of speech and assembly, consistent with their overall theory. Yet, it should be said, that even the existence of a theory of press liberty, an institution with "horizontal" implications and one addressed to public, not legislative, deliberation, suggests that the

\footnotetext{
${ }^{299}$ See, for example, James Ceaser, Presidential Selection, in J. Tulis and J. Bessette, eds, The Presidency in the Constitutional Order 234, 248-49 (LSU 1981) (describing the Founding Fathers' belief that issue appeals should not play a role in presidential elections); Jay B. Hubbell and Douglas Adair, Robert Munford's The Candidates, $5 \mathrm{Wm} \&$ Mary Q 217, 221, 224, 236 (1948); Charles S. Sydnor, American Revolutionaries in the Making (formerly published as Gentlemen Freeholders) (Free 1952) (describing the issueless character of elections in colonial Virginia).

${ }^{210}$ McRee, 2 Life and Correspondence of James Iredell at 505 (cited in note 128). See also Extracts, Albany Centinel 3 (Sept 21, 1798) (" $[\mathrm{In}]$ both Houses of Congress . . men [are] selected for their virtue, integrity, and talents.").

${ }^{211}$ A Friend to Order, Columbian Centinel 1 (Aug 4, 1798). See also John Adams, Defence of the Constitutions of Government of the United States, in Kurland and Lerner, eds, 1 The Founders' Constitution 400, 400 (cited in note 161).

${ }^{212}$ Federalist 35 (Hamilton) at 215 (cited in note 155). See also Hartford Connecticut Courant (Nov 27, 1786; Feb 5, 1787) (stating that the people should be "choosing men for their abilities, integrity and patriotism" rather than political patronage), as quoted in Gordon S. Wood, Representation in the American Revolution 46 (Virginia 1969); Andrew Eliot, A Sermon Preached before his Excellency 36, 50, 51 (Green \& Russel 1765) (stipulating that those elected for public office should possess "a larger proportion of understanding and integrity" than the commonality, and that they should "fear God").
} 
Federalists were accommodating developments that would eventually destroy the Federalist system.

\section{F. The Unavailability of Federalist Thought}

Though unsettling, the Federalist theory of democracy is pertinent to many of our modern democratic problems. Democratic theorists distraught with the superficiality and manipulation of mass political communications, or enthralled (as most are today) with the possibilities of "deliberative democracy," and republican lawyers looking for justifications for greater state regulation of communications have much to interest them here. Instinctively, however, most modern citizens sense Federalist ideas as being unacceptable and undemocratic, and it is worth discovering in a more precise way why we feel this way. Paradoxically, the very reasons that make Federalist theory unacceptable from modern perspectives made it both necessary and democratic from the Federalists' perspective. Delegating the deliberative process introduces a structural elitism that only makes sense in terms of epistemological assumptions and material circumstances that are no longer accurate or accepted. By examining the core assumptions that justified Federalist deliberation, this Section demonstrates why their theory of representation, at least how they formulated it, cannot be adopted in the modern world.

Representation, always "elitist" since activities are performed by representatives instead of the people themselves, is even more so regarding the "thinking" process of democratic politics, that is, deliberation. Since through deliberation (and interaction) disparate, uncoordinated, and inchoate elements are transformed into broader perspectives and considered judgments, the whole is always greater than the sum of its parts. Because the end product, the considered judgment of the community, is not in the people's possession, their relationship to their agents is compromised, lacking the capacity for complete evaluation. This fact shifts the Federalist conception of the representative in the direction of a fiduciary, still an agent but with elements of a trustee. ${ }^{213}$ This is analogous to the relationship between client and attorney where the agent is hired precisely because her expertise makes her in some sense the principal's superior.

\footnotetext{
${ }^{213}$ Theorists have pointed out that a representative is at once both a trustee for his constituents as well as their agent. A trustee, of course, acts in his principal's best interest but not under his direct control; whereas an agent may be following explicit instructions with little latitude for independent action. The question is just that of emphasis. See Pitkin, The Concept of Representation at 144 (cited in note 16).
} 
As the attorney analogy demonstrates, this is not necessarily an absurd arrangement. It was premised on three core Federalist assumptions: that the people physically could not deliberate, that politics was about finding the "right" answers, and that some people, through education and experience, were more capable of finding these answers. A brief review of how Federalists put these elements together is illustrative.

It is essential in understanding the Federalist perspective to appreciate their contention that different localities possessed only some of the elements necessary to political deliberation, and that it was only the representatives who could put them together. Their comments on this subject have geographical as well as social implications. The people in their constituencies, unaided by the process of exchange and interaction that occurs in deliberation, and lacking education and broader contacts, were frequently characterized as having "a local or partial view." 214 It was the representatives' job to develop this opinion, and this is what Noah Webster meant when he said, "The design of representation is to bring the collective interest into view."215 In other words, the "collective interest" only appears once elected officials have met and discussed. It does not precede them and is not present in the people considered by themselves. ${ }^{216}$ Another said as much in stating that "the real wants and wishes of the community, [are] collected ... [and] conveyed to that common center"; by adding that "the public wisdom ... and virtue [were] collected, also," he suggested that it was the social elite mediating the information. ${ }^{217}$

Repeatedly in Federalist literature the incomplete nature of political information as it exists among the people themselves was pointed to in arguing that the people were in no position to judge or oppose government. For example, a writer in Maine at-

${ }^{214}$ Debate in House of Representatives, Aug 15, 1789, in Kurland and Lerner, eds, 1 The Founders' Constitution at 413 (cited in note 161). See also Pole, Political Representation in England at 487-88 (cited in note 167) (explaining that the English people of the time believed that "[l]ocal people knew the details of local questions; they could not be expected to grasp the affairs of state," and therefore it was the role of Parliament "to transform all these local impulses into an opinion as to the national interest").

${ }^{215}$ Noah Webster, An Examination into the leading principles of the Federal Constitution, in Paul Leicester Ford, ed, Pamphlets on the Constitution of the United States, Published during its Discussion by the People, 1787-1788 25, 40 (Da Capo 1968).

${ }^{211}$ Other scholars have commented that the purpose of representation was understood differently in the eighteenth century, and that it was not thought of as expressing the people's will. See, for example, Buel, $21 \mathrm{Wm} \&$ Mary $Q$ at 166 (cited in note 22) (commenting that "[t]hough modern representative institutions are popularly regarded as the principal mechanism through which the people express their will in politics, this does not mean they were viewed in the same light by the Revolutionary generation almost two centuries ago").

${ }^{217}$ Tammany Society, To the People of the United States at 206-07 (cited in note 74). 
tacked a resolution of a Democratic-Republican society criticizing the actions of Congress by sarcastically asking club members to state their social and economic background, and insisted they prove they had the "wisdom [and the] means of information to censure the doings of Congress."

In a more extended piece Minister Samuel Kendal made the same points. In explaining why legislatures, not the people, must form the "national will," and why members of the public must consequently be deferential, he said:

If part are dissatisfied with certain measures, they ought to remember that the minds of our rulers are the focus, into which the rays of political light and information are collected, that they are actuated by a regard to general utility, and not so much by a view to local interest, and that they must, from their situation, be better able to judge what measures will promote the general good, with the least prejudice to local interest, than those can be, who do not enjoy the same means of information. ${ }^{219}$

He went on to explain that though "individuals, or small associations" may "catch a passing ray of political light" and "hastily form their sentiments," the fact that they cannot see the big picture means they should not "arrogate to themselves the character of the most fit and capable judges." 220 If they are so foolish as to "indulge such a humour [they will] censure measures, of which they are very inadequate judges, or which the partiality of local and interested views, rather than a regard for the general utility, leads them to censure."221

This particular understanding of the political process meant that elected officials not only possessed the right but the obligation to ignore public opinion on occasion. As Stephen Higginson explained, "when the expediency of a measure is clear to those who have the means of forming a right Judgement, and who alone are the regular constituted Judges of it, there can not be such a deference due to popular Opinion, still less to a Clamour only.".222

\footnotetext{
${ }^{218}$ From the Gazette of Maine, Columbian Centinel 2 (Sept 6, 1794).

${ }^{219}$ Kendal, Thanksgiving Sermon at 28 (cited in note 30 ).

${ }^{200}$ Id.

${ }^{221}$ Id. As Edward Bangs explained, "We are supposed to delegate our most intelligent men to manage our public affairs; and we ought generally to repose a confidence in them, as better informed than ourselves." Edward Bangs, An Oration on the Anniversary of American Independence, Pronounced at Worcester, July 4, 1800 19-20 (Worcester 1800).

${ }^{22}$ Stephen Higginson, 13 Aug. 1795, to T. Pickering, in 1 Letters of Stephen Higginson, 1783-1804 789 (Hist Assn 1896), quoted in Formisano, Transformation of Political Culture at
} 
This notion that the representatives deliberate for the people translates not into the modern idea that the representatives should do as the people want, but rather into the idea that the representatives should do as the people would want if only they had the same perspective as the representative. In other words, what the people would want if the ingredients necessary for political decision were present amongst them as they are concentrated amongst the representatives. In dismissing criticism of government, Timothy Dwight explained "that the officers of government are possessed of better information than private persons can be; that, if [ordinary people] had the same information, they would probably coincide with the opinions of their rulers."223

The assumption that the people could not deliberate was not unreasonable during the Federalist era. Communications were quite primitive, and newspapers, the only form of mass communication, were expensive and largely restricted to the urban areas. ${ }^{24}$ What is more, this geographic and technological justifica-

$405 \mathrm{n} 20$ (cited in note 15). Another example would be the explanation that the radical democrats' attempts to politically agitate the people were "dangerous" because "[t]he people collectively, cannot judge for themselves, so accurately as an intelligent legislature, selected particularly for that purpose." Davis, An Oration at 15 (cited in note 77). Reflections of this belief that the people could not and should not make their own political decisions can be found in any number of places. It is behind the distrust of popular power so often exhibited in The Federalist. See especially numbers 63 (Madison), 71 (Hamilton), 49 (Madison), 62 (Madison), 68 (Hamilton), in Rossiter, ed, The Federalist Papers (cited in note 84).

${ }^{2}$ Dwight, The Duty of Americans at 1386 (cited in note 108). This quotation, however, is uncharacteristic of Federalism in general and is more frequently found in Anti-Federalist writing because it suggests that all the people lack is information, an idea with egalitarian implications most Federalists chose to avoid. Many of Dwights other comments do have the hierarchical implications traditionally associated with the Federalists.

${ }^{221}$ The transportation and communication revolution that created the modern world, though beginning in the late eighteenth century, really came to fruition only during the first half of the nineteenth century. Newspapers, the only element then existing that might arguably be a part of a system of modern mass communications, had only begun in the eighteenth century, and they were still too limited in their impact to really serve the same function as their modern counterparts. As several scholars said of the colonial and revolutionary press, "[T] hese weekly papers could not be regarded as instruments of mass communication. Their circulations were small (usually a thousand copies or so), and they were relatively expensive." Kenneth Janda, Jeffrey M. Berry, and Jerry Goldman, The Challenge of Democracy: Government in America 308 (Houghton Mifflin 1st ed 1987). See also G.A. Cranfield, The Development of the Provincial Newspaper, 1700 to $1760168-89$ (Calerdon 1962) (commenting on the affluence of those who bought newspapers); L. Roth, The Colonial Printer 169-90 (Clarendon 2d ed 1938) (same), cited in Patrick Garry, The First Amendment and Freedom of the Press: A Revised Approach to the Market Place of Ideas Concept, 72 Marq L Rev 187, 215 n 135 (1989); Formisano, Transformation of Political Culture at $407 \mathrm{n} 30$ (cited in note 15) (commenting on the minimal impact of the newspapers). See generally Michael Emery and Edwin Emery, The Press and America, an Interpretive History of the Mass Media (Prentice Hall 7th ed 1991); Elizabeth L. Eisenstein, 1 The Printing Press as an Agent of Change (Cambridge 1979); Frank Luther Mott, American Journalism: A History of Newspapers in the United States Through 250 Years, 1690- 
tion was self-consciously stressed in much literature. "[H]ow are these millions of students to have access to the means of information?" asked Fisher Ames. ${ }^{225}$ For as Ames bluntly put it, "the people as a body cannot deliberate."226 John Adams said that the people "can never act, consult, or reason together because they cannot march five hundred miles, nor spare the time, nor find a space to meet."227 Given the geographical dispersion of the people and the comparative absence of mass communications and effective transportation, the Federalists were well justified in their claim that, if any democratic deliberation was to take place at all, it had to occur in the legislature and not among the people themselves. Thus, the Federalist theory was the most democratic one possible in its historical context.

In the modern context, however, the problem would not be how to enable the people to deliberate, but rather how to keep them from doing so. In defense of the Federalist theory, one can still say that discussion among full-time legislators is of a higher quality than that occurring via mass communications and political organizations, and that participation through representatives is more equitably distributed. These are not small points. But the geographical and technological necessity of delegating deliberation is now absent, and it was already vanishing during the Federalist era.

The other two foundational Federalist assumptions enjoy a similarly doubtful status today. As the "republican revolution" in historiography has demonstrated, classical, Aristotelian patterns

1940 (MacMillan 1941); William David Sloan, et al, The Media in America, A History (Publishing Horizons 2d ed 1993).

Added to this must be the fact that these papers had virtually no penetration into rural areas, where 90 percent of the population lived. A journalist, commenting on why Pennsylvania's abolition of slavery had had no impact on the few slaveholders in rural areas, said it was probably because they had not heard of the law, since "newspapers ... circulated only in the city." The Pennsylvania Gazette (May 18, 1785).

Mass communications beget mass political organizations, so the absence of the former explains the dearth of the latter. Consistent with this theory of newspaper effectiveness, mass political organizations such as political parties did not exist in the United States until at least the 1830s. See Ronald P. Formisano, Deferential-Participant Politics: The Early Republic's Political Culture, 1789-1840, 68 Am Pol Sci Rev 473 (1974); William G. Shade, Political Pluralism and Party Development: The Creation of a Modern Party System: 18151852, in Paul Kleppner, et al, eds, The Evolution of American Electoral Systems 77 (Greenwood 1981).

${ }^{225}$ Ames, The Dangers of American Liberty at 1317 (cited in note 82).

${ }^{205} \mathrm{Id}$.

${ }^{227}$ John Adams, A Defence of the Constitutions of Government of the United States of America, in George A. Peek, Jr., ed, The Political Writings of John Adams 105, 146 (Liberal Arts Press 1954). See also Noah Webster, An Oration on the Anniversary of the Declaration of Independence (New Haven 1802), in Hyneman and Lutz, eds, 2 American Political Writings 1220, 1230-32 (cited in note 82). 
of thought, including the belief that the common good was objectively discernable, were still powerful in the Federalist period. ${ }^{228}$ If the common good is objective, political issues have "best" answers, and the class of people most capable of discerning these answers are society's "natural aristocrats."229 The Federalists, frankly aristocratic, believed the wealthy and educated were best prepared to understand political questions. ${ }^{230}$

If one could accept their assumptions, the Federalist idea of electing an elite is quite democratic. Just as a poor and uneducated individual is best represented not by himself but by a rich and educated lawyer, despite their social dissimilarity, if politics has right answers and aristocrats know more of them, it would hardly serve the people's interests to elect anyone else. The lawyer pursues the client's interest in the context of something the client does not know, the law, and the Federalist politician pursues the people's interests in the context of something the people do not know, politics. While people today accept that there are "better" answers and experts who know them in technical subjects like engineering, they do not think this applies to politics. We are either skeptical that there are "political truths," or skeptical of recognizing a class that possesses them. ${ }^{231}$ As a result, the people are forced to decide for themselves. After all, while a principal may delegate to an agent the authority to shepherd her through an area the agent knows better than she does, the idea of a principal delegating to an agent the authority to decide for her what she wants is problematic indeed. For these reasons democracy is generally understood in terms of the aggregation of popular preferences and the formation of popular will. The Federalists

${ }^{223}$ See Richard H. Fallon, Jr., What is Republicanism and is it Worth Reviving?, 102 Harv L Rev 1698 (1989); Horwitz, 29 Wm \& Mary L Rev at 67-69 (cited in note 6).

${ }^{229} \mathrm{John}$ Adams and Thomas Jefferson are most noted for their use of this term, although the expression was used by many. Adams speaks of "the rich, the well-born" in his Defence of the Constitutions at 115 (cited in note 227). See also Thomas Jefferson, To John Adams, in Merrill D. Peterson, ed, The Portable Thomas Jefferson 533, 534 (Viking 1975); Gordon Wood, The Radicalism of the American Revolution 1-95 (Knopf 1992) (discussing the elitism of colonial culture, which Wood thought slowly diminished until the age of Jackson).

${ }^{200}$ The Federalist notion of delegating deliberation, it might be added, really demands such a "political class" and a conception of the common good. Without them, what will be the basis of electoral selection? The people cannot vote for candidates on the basis of their programs-the people are not competent to judge these-and the politicians need a standard, the common good, by which to guide their behavior. They cannot use public opinion.

${ }^{221}$ Compare David Estlund, Making Truth Safe for Democracy, in David Copp, Jean Hampton, and John E. Roemer, eds, The Idea of Democracy 1-100 (Cambridge 1993), with with David Copp, Could Truth be Hazardous for Democracy?, in Copp, Hampton, and Roemer, eds, The Idea of Democracy 101-17. 
nevertheless had a point. Some people are more politically informed than others, and relying on the public to make decisions, when most individuals have neither the time nor the interest in investigating political issues, markedly lowers the quality of democratic decisions.

\section{CONCLUSION}

The fact that the Federalist system is based on unacceptable premises, however, does not mean it is irrelevant. The central lesson of the Federalists-that representation is inseparable from repression, and that this applies to discussion as well as other political processes-has many potential applications. As part of our constitutional inheritance, elements of this theory can be adopted in places and utilized to modify our predominantly liberal interpretation of First Amendment law. Obviously it justifies a greater role for the state in regulating the mediums in which public deliberation takes place. The context and quality of public debate, as well as how democratically participation is distributed, are considerations to be taken into account in structuring the forums in which such debate takes place. The party that gave us the Constitution did not intend for public deliberation to be highjacked by small minorities of active but unrepresentative citizens. This can only be good news, considering the fact that viewing participation as an inviolable personal right has led to government by special interests ruling over a fairly apathetic and ill-informed public. ${ }^{232}$ None of this, of course, is meant to suggest that the Sedition Act or the campaign against the clubs were anything more than rear-guard actions. The understanding of representation and the Constitution the Federalists sought to preserve died for historically irreversible reasons. But history has not stopped changing. Given the tremendous decline in political participation that has occurred during this century, perhaps some of these Federalist ideas have become relevant again.

\footnotetext{
${ }^{202}$ Modern research suggests that a system such as the Federalists envisioned, where deliberations are restricted to the representatives themselves, would actually be more democratic. Some scholars have argued that representatives act in a more "representative" manner when legislative actions cannot be directly traced to them-in other words, when they are less accountable-because such a system insulates them from the pressure of special interest groups whose views are not representative. The predominant view of today, that open processes are more democratic than closed ones, is thus simply mistaken. See $\mathbf{R}$. Douglas Arnold, The Logic of Congressional Action ch 10 (Yale 1990).
} 